\title{
Osteoporosis in Frail Patients: A Consensus Paper of the Belgian Bone Club
}

\author{
E. Gielen ${ }^{1} \cdot$ P. Bergmann ${ }^{2} \cdot$ O. Bruyère ${ }^{3} \cdot$ E. Cavalier $^{4} \cdot$ P. Delanaye ${ }^{5} \cdot$

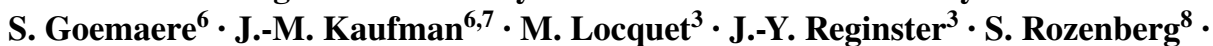 \\ A.-M. Vandenbroucke ${ }^{9} \cdot$ J.-J. Body ${ }^{10}$
}

Received: 9 January 2017 / Accepted: 2 March 2017 / Published online: 21 March 2017

(c) The Author(s) 2017. This article is an open access publication

\begin{abstract}
In this consensus paper, the Belgian Bone Club aims to provide a state of the art on the epidemiology, diagnosis, and management of osteoporosis in frail individuals, including patients with anorexia nervosa, patients on dialysis, cancer patients, persons with sarcopenia, and the oldest old. All these conditions may indeed induce bone loss that is superimposed on physiological bone loss and often remains under-recognized and under-treated. This is of particular concern because of the major burden of osteoporotic fractures in terms of morbidity, mortality, and economic cost. Therefore, there is an urgent need to appreciate bone loss associated with these conditions, as this may improve diagnosis and management of bone loss and fracture risk in clinical practice.
\end{abstract}

Keywords Osteoporosis - Frailty · Cancer · Dialysis . Elderly $\cdot$ Sarcopenia $\cdot$ Anorexia nervosa

E. Gielen

evelien.gielen@uzleuven.be

1 Gerontology and Geriatrics, Department of Clinical and Experimental Medicine, KU Leuven \& Center for Metabolic Bone Diseases, UZ Leuven, Herestraat 49, 3000 Leuven, Belgium

2 Department of Radioisotopes, CHU Brugmann, Université Libre de Bruxelles, Bruxelles, Belgium

3 Department of Public Health, Epidemiology and Health Economics, University of Liège, CHU de Liège, Liège, Belgium

4 Department of Clinical Chemistry, UnilabLg, CIRM, University of Liège, CHU de Liège, Liège, Belgium

5 Department of Nephrology, Dialysis, Transplantation, University of Liège, CHU de Liège, Liège, Belgium

\section{Introduction}

Life expectancy has increased substantially over the past centuries. Along with the aging of the population, the incidence of age-associated conditions increases and more attention and resources will be needed to manage these conditions. Osteoporosis, characterized by low bone mineral density (BMD) and microarchitectural deterioration of bone tissue associated with bone fragility and fracture risk, is of particular concern because of the major burden of osteoporotic fractures in terms of morbidity and mortality. BMD is not the sole criterion to determine fracture risk. An overall fracture risk assessment that combines multiple risk factors such as the WHO FRAX algorithm provides a more accurate evaluation.

Fracture probability estimated with the FRAX algorithm is, however, underestimated in patients with certain conditions. For example, in the FRAX algorithm, anticancer treatment is not considered as a specific risk factor nor does

6 Unit for Osteoporosis and Metabolic Bone Diseases, Ghent University Hospital, Ghent, Belgium

7 Department of Endocrinology, Ghent University Hospital, Ghent, Belgium

8 Department of Gynaecology-Obstetrics, Université Libre de Bruxelles, Bruxelles, Belgium

9 Clinical Department of Internal Medicine, UZ Leuven, Leuven, Belgium

10 Department of Medicine, CHU Brugmann, Université Libre de Bruxelles, Bruxelles, Belgium 
this algorithm include a "renal" parameter or a measure of sarcopenia and fall risk. Therefore, fracture risk in patients on some anticancer treatments, dialysis, or with severe kidney disease or sarcopenia may be underestimated. Other risk factors such as age and low body mass index (BMI) are included in the FRAX algorithm. However, the algorithm accepts only ages between 40 and 90 years, so not the very elderly and most of the patients with anorexia nervosa (AN), who, in general, are younger than 40 years. Also the management of osteoporosis in the oldest old and in patients with AN is of interest because currently approved therapies for osteoporosis have mainly been investigated in persons until the age of 75 years and are not indicated for use in young individuals.

Reducing fracture risk in frail individuals is of major importance because of the morbidity and mortality associated with fragility fractures. In this consensus paper, we will review the current evidence about the evaluation and management of osteoporosis in frail persons, namely in patients with AN, patients on dialysis, cancer patients, persons with sarcopenia, and the oldest old. Osteoporosis in other frail subsets of the population, such as in HIV positive patients and patients with diabetes mellitus, will not be discussed.

\section{Osteoporosis in Patients with Anorexia Nervosa}

The estimated lifetime prevalence of anorexia nervosa (AN) ranges between $0.6 \%$ and $4.2 \%$, but these estimates are likely to be low due to the tendency of some individuals to conceal their illness [1]. AN is 10 times more common in women than men. In this section we will, therefore, discuss only women affected by AN and osteoporosis. The median age of onset of AN is 18 years [1]. The psychological profile of young women with AN is that of women driven to excel, pressurized to fit a specific body image. Osteoporosis is common in AN. About half of these patients suffer from osteoporosis and almost all from osteopenia [2]. Although amenorrhea is not anymore required in the definition of $\mathrm{AN}$, amenorrhea is common and the typical triade consists of low energy intake (generally related to eating disorders), osteoporosis, and amenorrhea.

\section{Etiology}

AN is associated with marked endocrine changes that also impair healthy bone turnover. As mentioned before, amenorrhea is common. In adolescents with AN, menarche is often delayed, contributing to low BMD. However, the severity of bone loss in women with AN is greater than in those with normal-weight hypothalamic amenorrhea, indicating that, in addition to estradiol deficiency, there are other factors including nutritional deficiencies and hormonal abnormalities that contribute to bone loss. GH resistance, low levels of IGF-1, hypercortisolemia, and low levels of testosterone have all been implicated in $\mathrm{AN}$-associated osteopenia and osteoporosis. Abnormalities in hormones regulating appetite (oxytocin, leptin, and peptide tyrosine tyrosine (PYY)) may play an additional role [1]. Therefore, the etiology of bone loss in patients with AN is multifactorial.

\section{Biological Markers of Bone Turnover}

Klibanski et al. observed an uncoupling of bone turnover in adults with AN, with a decrease in markers of bone formation and an increase in markers of bone resorption. However, in adolescents with AN, there is a low bone turnover state with a decrease in the levels of bone formation and resorption, as opposed to an increased bone turnover during normal adolescence [3]. Veronese et al. conducted a meta-analysis of vitamin D status in AN patients [4]. They identified 15 studies (totalizing 927 participants; $\mathrm{AN}=408$ and healthy controls $=519$ ) and observed that, although AN patients reported similar dietary vitamin D intake compared to healthy controls, AN patients had significantly lower levels of $25 \mathrm{OHD}$ and $1,25(\mathrm{OH})_{2} \mathrm{D}$ when not using vitamin $\mathrm{D}$ supplementation. Conversely, supplementation with cholecalciferol fully normalized serum levels of vitamin D [4].

\section{Bone Loss and Fracture Risk}

Both trabecular and cortical bone sites are affected in AN, but since there is a marked estrogen deficiency component in these women, trabecular osteoporosis (such as at the lumbar spine) is more frequent and prominent [5]. Based on HR-pQCT studies, it has been suggested that bone geometry, microarchitecture, marrow adiposity, as well as bone strength estimates are affected [5]. When AN affects women before reaching their peak bone mass, a reduced bone accrual will impeach them from attaining the optimal BMD, increasing their risk of fracture [6].

Not surprisingly, therefore, a two- to sevenfold increase in fractures has been reported in patients with $\mathrm{AN}[7$, 8]. Rigotti et al. followed a series of 27 women with AN for a median of 25 months and concluded that anorectic women have an increased risk of fracture (RR 7.1; 95\% CI 3.2-18.5) and that BMD reductions appear not to be rapidly reversed by recovery from AN [7]. Vestergaard et al., using a case-control Danish Nationwide register study, also observed an increased fracture risk in AN, which persisted more than 10 years after the diagnosis [8]. 


\section{Assessment and Management of Osteoporosis in AN}

The clinical assessment involves an osteoporosis assessment consisting of BMD measurement and assessment of other risk factors for osteoporosis such as a personal history of low-trauma fractures, a family history of osteoporotic fractures, lifestyle factors, medication, and serum level of 25OHD. In addition, checking for reproductive dysfunction (amenorrhea, follicle-stimulating hormone (FSH), luteinizing hormone (LH), estradiol) and measuring prolactin, thyroid-stimulating hormone (TSH), and human chorionic gonadotropin (hCG) is needed to rule out causes of amenorrhea other than AN.

Table 1 gives an overview of the management of low bone density in patients with AN. AN patients need to be encouraged to gain weight. Recovering a near-normal or normal BMI $\left(18-25 \mathrm{~kg} / \mathrm{m}^{2}\right)$ will generally help to recover a normal reproductive functioning, which can be assessed by a regular menstrual cycle (not using hormone therapy). Restoration of body weight will also improve BMD although a complete catch-up does not always occur [5]. In addition, AN patients should take adequate calcium (e.g., $1200 \mathrm{mg}$ ) and vitamin D (e.g., $800 \mathrm{IU}$ ) daily, from diet and supplements.

High-dose estrogen-progestin contraception is not an effective treatment option for $\mathrm{AN}$-associated bone loss in adolescents or adults. Indeed, prospective trials have failed to show a benefit of combination estrogen-progestin oral contraceptives in treating $\mathrm{AN}$-associated bone loss in adolescents or adults, although one may be tempted to restore menstruation in these patients using oral contraceptives. Unfortunately, several studies have failed to observe a protective effect of the "pill" containing $50 \mu$ g ethynilestradiol [11]. On the other hand, lower-dose physiologic estrogen replacement using MHT such as $100 \mu \mathrm{g}$ transdermal 17-beta-estradiol with cyclic micronized progesterone in adolescents resulted in BMD gains at the spine and hip compared with placebo, though the therapy did not restore BMD to normal [10]. Although AN patients are also deficient in androgens, androgen replacement is currently not recommended.

Limited data suggest that bisphosphonates may be of benefit in women with $\mathrm{AN}$-associated bone loss. For instance, risedronate for 1 year resulted in a modest gain in BMD compared with placebo [13]. Another study, however, failed to report an improvement using alendronate $v s$. placebo [14]. Furthermore, there are safety concerns with bisphosphonates especially in younger patients who may want to become pregnant. Indeed, animal studies have suggested placental transfer of bisphosphonates and fetal skeletal development involvement, and in a small series of 10 women treated with bisphosphonates during pregnancy,

Table 1 Management of low bone density in AN

\begin{tabular}{|c|c|c|}
\hline & Adolescent girls & Postmenopausal women \\
\hline Lifestyle advise & $\begin{array}{l}\text { Decrease exercise and increase weight gain } \\
\text { Calcium and vitamin D }\end{array}$ & $\begin{array}{l}\text { Decrease exercise and increase weight gain } \\
\text { Calcium and vitamin D }\end{array}$ \\
\hline \multicolumn{3}{|c|}{ When to initiate pharmacological therapy? } \\
\hline FRAX & $\begin{array}{l}\text { (FRAX is not intended for use in persons }<40 \\
\text { years) }\end{array}$ & No specific guidelines for adults with AN \\
\hline DXA & $\begin{array}{l}\text { Z-score } \leq-2+\text { decreasing over time despite all } \\
\text { efforts at weight gain }[5,9]\end{array}$ & No specific guidelines for adults with AN \\
\hline \multicolumn{3}{|c|}{ Which pharmacological therapy? } \\
\hline Recommended & $\begin{array}{l}\text { Lower-dose physiologic estrogen [10] } \\
\text { MHT (100 } \mu \mathrm{g} \text { transdermal 17-beta-estradiol } \\
\text { with cyclic micronized progesterone) }\end{array}$ & $\begin{array}{l}\text { In adults with osteoporosis } \\
\text { MHT ( } 100 \mu \mathrm{g} \text { transdermal 17-beta-estradiol with } \\
\text { cyclic micronized progesterone) in women aged } \\
50-60 \text { years* } \\
\text { Bisphosphonates* } \\
\text { Denosumab* } \\
\text { (schemes \& doses for postmenopausal osteopo- } \\
\text { rosis) }\end{array}$ \\
\hline Not recommended & $\begin{array}{l}\text { High-dose estrogen (oral contraception) [11] } \\
\text { (“pill” containing } 50 \mu \mathrm{g} \text { ethynilestradiol) } \\
\text { Androgen replacement [5] } \\
\text { Recombinant human insulin-like growth factor } \\
1 \\
\text { (rhIGF-1) (under investigation) [5] } \\
\text { Bisphosphonates } \\
\text { Denosumab } \\
\text { Teriparatide }\end{array}$ & $\begin{array}{l}\text { In adults with AN-associated bone loss } \\
\text { Additional research is needed to confirm efficacy } \\
\text { and safety of bisphosphonates [12] } \\
\text { No data regarding use of Denosumab [5] } \\
\text { Role for Teriparatide not yet clear (under investi- } \\
\text { gation) [5, 12] }\end{array}$ \\
\hline
\end{tabular}

*Few series 
congenital malformations were reported in 20\% [15]. Although most other data in literature suggest that preconceptional and first-trimester use of bisphosphonates do not pose substantial fetal risks, it is recommended that, when bisphosphonates are prescribed to females of reproductive age, one should ensure that the patient is and will not become pregnant when using bisphosphonates [15]. Bisphosphonates are generally not approved for this indication, but may be used in elderly with AN. Also denosumab and teriparatide should not be used as first-line therapies in young patients suffering from $\mathrm{AN}$-induced osteoporosis.

\section{Conclusion}

AN predominantly affects women at a young age. As a result, almost all endocrine axes are disturbed. This will lead to osteoporosis in about half of the patients and to osteopenia in almost all of them. The burden due to fractures is important. A multidisciplinary management is needed, involving a gynecologist, endocrinologist, pediatrician (depending of the patients' age), psychologist, nutritionist, and bone specialist. BMD measurement and an endocrine evaluation are mandatory. Other pathologies associated with weight loss, amenorrhea, and bone loss should be excluded. The ultimate therapy implies body weight restoration and regular cycle recovery. A healthy lifestyle is therefore mandatory. Calcium and vitamin D supplementation is recommended in all patients with AN. MHT is indicated in adolescent girls with sustained low weight, low BMD, and amenorrhea when other causes of amenorrhea have been excluded. Bisphosphonates and denosumab may be useful in adult women with severe bone loss.

\section{Osteoporosis in Dialysis Patients}

\section{Fracture Risk in Dialysis Patients}

Dialysis status is associated with an outstanding risk of fracture compared to the general population. In 2006, results from the international observational cohort DOPPS (Dialysis Outcomes and Practice Patterns Study) were published. Such as in the general population, the risk of hip fracture in the dialysis population was higher in women and increased progressively with age, but, in both genders and in all age categories, the incidence of hip fracture was much higher in dialysis patients. For example, the incidence of fracture in women between 75 and 84 years was 1190 and 3136 per 100,000 patients in the general and dialysis population, respectively [16]. Similar data from USRDS (United States Renal Data System) showed a fourfold higher risk of fracture in dialysis compared to the general population [17]. There is also evidence that these fractures occur earlier in life, and fractures in hemodialysis are associated with higher morbidity and even mortality. A mortality rate as high as $64 \%$ in the year following a hip fracture has been described in dialysis patients [18]. Of course, the risk of fracture is also tightly associated with the high risk of falls in this population, which is enhanced by factors such as older age, diabetes, depression, antidepressants, previous falls, malnutrition, and frailty.

\section{Osteoporosis in Dialysis Patients: Bone Mass Versus Bone Turnover}

In clinical practice, bone fragility is evaluated by DXA that measures both cortical and trabecular bone quantity. New CT-scan techniques (quantitative computed tomography (QCT) or high-resolution peripheral QCT (HR-pQCT)) are now available and currently used in clinical research with the main advantage of being able to separate cortical and trabecular areas [19-21]. However, bone quantity is only one piece of the puzzle. Indeed, bone strength, and thus fracture risk, is dependent not only on bone quantity but also on bone quality which is determined by both bone turnover and mineralization, concepts being assessed by bone biopsy and histomorphometry [19, 22].

Bone disorders have been described for more than a century in chronic kidney disease (CKD) patients [22]. In 2006, the international KDIGO (Kidney Disease: Improving Global Outcomes) guidelines proposed a common terminology using the term "Chronic Kidney Disease-Mineral and Bone Disorder" (CKD-MBD) to encompass all possible abnormalities associated with bone disease and mineral disturbances [23]. CKD and still more dialysis status is associated with severe mineral abnormalities, such as hypocalcemia, hyperphosphatemia, and secondary hyperor hypoparathyrodism. It is beyond the scope of this article to review the pathophysiology of such abnormalities [23, 24] but basically they will be associated with either low ("adynamic bone disease") or high ("osteitis fibrosa") bone turnover disease in dialysis patients [22]. The vast majority of basic and clinical research in nephrology is thus focused on turnover abnormalities, and by consequence more on bone quality (turnover) than on bone quantity (osteoporosis) [19]. Briefly, both low and high turnover seems associated with an increase of fracture risk [19-21, 23, 25]. Sensu stricto, such a diagnosis requires a bone biopsy but this technique remains relatively invasive, costly, and difficult to interpret and repeat. An important part of clinical research is thus about the role of biomarkers to estimate bone turnover [24]. Currently, the KDIGO recommends the measurement (and monitoring) of both parathyroid hormone (PTH) and bone-specific alkaline phosphatase (b-ALP), even if, 
as discussed later in this chapter, the interpretation of the results remains frequently difficult and sometimes disappointing [24].

\section{Diagnosis of Osteoporosis in Dialysis Patients: DXA, FRAX and Biomarkers}

Data on the utility of DXA in dialysis patients, notably for predicting the risk of fracture, are scarce and controversial in comparison to the literature in the general population. For this reason, but also because specific therapies for osteoporosis are not routinely used in dialysis, the KDIGO did not recommend routine DXA in dialysis patients when first published in 2009 [23]. This recommendation could, however, change in the next KDIGO recommendations. Indeed, a meta-analysis, including 6 studies and 683 (357 women) dialysis patients, suggested that low BMD was associated with fractures and this was true for all sites, except the femoral neck [26]. However, data were heterogeneous and only cross-sectional. A longitudinal observational study in 485 hemodialysis patients showed that DXA, especially at the hip region, was useful to predict incident fractures but only in patients with low PTH [25]. Beyond fracture risk, some authors suggested that in dialysis patients, osteoporosis and osteopenia were associated with an independent higher risk of mortality [27]. These data could lead to a broader use of DXA in dialysis patients in the future, even if currently the level of evidence is still relatively low. Therefore, at this time, a T-score threshold at which intervention should be started, cannot be recommended. Moreover, there are some specific technologic issues in dialysis patients. Indeed, these patients frequently suffer from spinal osteophytes and high vascular calcifications in the aorta making the interpretation of DXA results at the lumbar region questionable, with a risk of spuriously good results [19, 27]. It is thus suggested to measure BMD in the radius region, especially when there is secondary hyperparathyroidism, and this is another reason why QCT and HR-pQCT are of potential interest in dialysis patients [20].

FRAX does not include any "renal" parameter. This score has not been validated in dialysis patients and is thus considered neither in the KDIGO nor in clinical practice. Therefore, 10-year FRAX risks at which intervention should be initiated cannot be recommended.

If the available literature on bone biomarkers to detect and/or monitor bone turnover abnormalities in dialysis patients is abundant [24], current data on these biomarkers to detect and/or monitor osteoporosis are scarce and controversial. In the general population, biomarkers (especially $\beta$ C-terminal cross-linked telopeptide ( $\beta$-CTX) and N-terminal propeptide of type I procollagen (PINP)) may be used to monitor the response to osteoporosis therapy [28]. This is, however, not relevant in dialysis patients as nearly all osteoporotic treatments are not recommended in these patients. The current knowledge on the ability of such biomarkers to detect osteoporosis and/or to monitor bone loss is thus limited and controversial [21, 23]. A recent observational longitudinal study in 81 US dialysis patients measured several biomarkers as well as BMD by DXA and QCT at baseline and after one-year of follow-up [29]. At baseline and after multivariate analysis with age, gender, BMI, and ethnicity as covariates, an association was observed between DXA at the hip and baseline PTH and b-ALP (negative association) and sclerostin (positive association). At the spine, the associations were significant with PTH and sclerostin but also with FGF-23. Considering change in BMD over a one-year period, there was no association between change in BMD at the hip and any biomarker. At the spine, change in BMD was, however, associated with baseline FGF-23 values (negative association) and with change in sclerostin (positive association). The associations observed between change in BMD measured by QCT and biomarkers are also significant but with other biomarkers than those associated with DXA (for example, tartrateresistant acid phosphatase-5b) and the associations are also different according to the region (hip or spine) [29]. The association between BMD or change in BMD and biomarkers are thus very heterogeneous, making the interpretation of this study difficult. Moreover, each biomarker, including "simple" biomarkers like PTH, has its own analytical and clinical limitations (accumulation in CKD, high intra-individual variation, absence of normal reference values) [24]. Other studies on the same topic are thus urgently needed. For example, for PTH, second- and third-generation PTH assays are currently available, which measure 1-84 and 7-84 PTH ('intact' PTH assay) and 1-84 PTH only, respectively. KDIGO experts conclude that both the second- and the third-generation assays are similarly informative. However, the assays have high inter-method variability. Therefore, KDIGO proposes to use a target range for serum PTH based on multiples of the upper limit of the normal values rather than on absolute concentrations [24].

\section{Therapeutic Strategies in Dialysis Patients}

The majority of therapeutic studies in dialysis patients focused on bone turnover abnormalities with, for example, vitamin D or calcimimetics, although the majority of these studies used biomarkers, and not bone biopsies, as endpoint [19]. Clinical studies reporting fractures as hard clinical endpoint are even more scarce. One large RCT suggests that fractures could be reduced in dialysis patients with hyperparathyroidism when treated with calcimimetics [30]. This was, however, a post hoc analysis with statistical adjustments, while the primary study was negative for the fracture endpoint [31]. 
There are few studies about specific osteoporosis therapies in dialysis patients as dialysis status was an exclusion criterion in all large interventional trials on this topic [19-21]. The role of bisphosphonates in dialysis patients is still a subject of debate. Data in literature are scarce in severe CKD non-dialysis patients and even more limited in dialysis patients [20]. Some publications, however, suggest positive results on BMD [32]. Because 50\% of the administered dose of bisphosphonates gets excreted by the kidneys, the dosage used in these studies is lower than in the general population. Limitations of these studies are the design, sample size, and follow-up (6-12 months). In theory, bisphosphonates are contraindicated in patients with low bone turnover. For this reason, the KDIGO recommends to perform a bone biopsy before a potential treatment with bisphosphonates. Also raloxifene has been hardly studied in dialysis patients. The safety profile seems acceptable in postmenopausal women on hemodialysis, but long-term data are lacking. The beneficial impact on BMD has been suggested by some prospective and sometimes randomized studies but the sample sizes and follow-up times were always limited (at best 26 patients in the treated group and follow-up of 1 year) [33]. Likewise, there are few clinical data on the benefit of strontium ranelate in dialysis patients and some authors have underlined the risk of osteomalacia with this treatment in dialysis patients [34]. Recent osteoporosis therapies have theoretical interest in dialysis patients. Denosumab has been shown to be effective in dialysis patients but the numbers of included patients were low and all studies were open-label and non-randomized. Moreover, dialysis patients are at higher risk of developing severe hypocalcemia with denosumab [35]. According to some authors, this antiresorptive therapy should also be avoided in dialysis patients with low bone turnover [20]. Teriparatide and other PTH analogs are theoretically interesting, especially in dialysis patients with low bone turnover but, once again, available data are limited to case reports and pilot studies [36]. Lastly, also in the context of low bone turnover disease, new anti-sclerostin antibodies could be beneficial but until now, only animal studies are available [37].

\section{Future Research}

Because of the high risk of fracture in dialysis patients, there is a clear interest to promote clinical research in the field of bone disease. Nephrologists should certainly move from an "only bone turnover" (bone quality) point of view to a broader vision including the concept of bone quantity. This change of concept is necessary because many new and potentially useful therapies are now available. However, there is still need to clarify the place of DXA, QCT, and biomarkers to predict the risk of fractures and/or to evaluate or monitor BMD.

Cardiovascular mortality is the first cause of death in dialysis patients. At least in part, vascular calcifications explain this cardiovascular over-mortality. The pathophysiology of these vascular calcifications has been suggested to share similar pathways with bone physiology. In the future, potential connections between bone (and osteoporosis) and vessels (and vascular calcifications) will be an interesting field of basic and clinical research. Some data suggest an inverse correlation between vascular calcifications and osteoporosis [20, 27]. Therefore, future studies with osteoporosis therapies should be designed with two endpoints; the effect on bone (BMD, biomarkers and ideally fracture) and the effect on vessels (vascular calcification and ideally cardiovascular mortality).

\section{Conclusion}

Dialysis status is associated with a major risk of fractures compared to the general population. Furthermore, fractures in dialysis patients occur earlier in life and are associated with a higher morbidity and mortality. The assessment of bone health and fracture risk in dialysis patients may be difficult because of the heterogeneous association between (change in) BMD and biomarkers. Moreover, the FRAX algorithm does not include dialysis status; DXA is, until now, not recommended by KDIGO and bone biopsies remain relatively invasive and difficult to interpret. Since dialysis status was an exclusion criterion in all large RCTs, the role of bisphosphonates is still a subject of debate. Denosumab has been shown to be effective but with a risk of developing severe hypocalcemia. Teriparatide and other PTH analogs may be interesting in dialysis patients with low bone turnover, in whom antiresorptives should be avoided.

\section{Osteoporosis in Cancer Patients}

The term "bone health" in cancer patients encompasses the impact of metastatic bone disease and the effects of cancer therapy on bone mass and fracture rate. Metastatic bone disease is most commonly seen with specific cancer types, notably those arising from the breast, prostate, lung, and kidney, as well as multiple myeloma. Bone metastases weaken the structural integrity of bone, putting patients at increased risk of bone complications, skeletal-related events (SREs), including pathologic fracture, spinal cord compression, or subsequent radiation or surgery to the bone. SREs are associated with increased morbidity and mortality, decreased quality of life, and increased treatment 
costs. Many patients with bone metastasis also experience bone pain that can be severe and debilitating. Antiresorptive agents markedly reduce the incidence of SREs and delay the occurrence of severe bone pain. The reader is referred to a recent review for this topic [38]. A second connection between cancer and bone is that most drugs used to treat hormone-responsive tumors have a deleterious indirect effect on bone turnover, BMD, and bone quality. In the elderly, cancer treatment-induced bone loss (CTIBL) is superimposed on physiological bone loss. This chapter focuses on CTIBL in breast cancer and prostate cancer in the adjuvant setting. There has been less interest for bone health in patients cured from other tumors, although bone loss after stem cell transplantation at last received more attention.

\section{Breast Cancer}

Aromatase inhibitors (AIs) increase overall survival in RCTs against tamoxifen and have become the first-line hormonotherapy in the adjuvant setting of breast cancer. Bone loss is their main side effect. AI therapy is associated with an average $2 \%$ loss of lumbar spine BMD per year, and the effects of AIs on cortical bone and bone strength appear to be largely underestimated by classical dualenergy X-ray absorptiometry (DXA) [39]. Risk of fracture is 2-4 times higher in women treated with adjuvant AIs than with tamoxifen or placebo [38, 39]. The increased risk is independent of the type of AI and, with the exception of ABCSG-18, the only trial where fracture incidence was the primary endpoint, the risk has been underestimated because fractures were only reported as adverse events in oncology trials. The absolute risk of fracture in women treated with AIs ranges from 1-18\%. Data from ABCSG18 show a fracture rate of $9.6 \%$ after 3 years and $26 \%$ after 7 years in the placebo group on AIs only [40].

Published guidelines recommend that women with breast cancer receiving an AI or ovarian suppression therapy have their bone health monitored for fracture risk, for example, with BMD measurement and the FRAX algorithm [38]. In FRAX, however, anticancer treatments are not included as a unique risk factor and enter in the "secondary osteoporosis" group, which underestimates the effect of these therapies on fracture risk [38]. As for other conditions characterized by an increased fracture rate, patients receiving AIs should be advised to consume a calcium-enriched diet and/or receive calcium supplements, exercise moderately (resistance and weight-bearing exercise), and take 1000-2000 international units (IU) of vitamin D everyday. Table 2 summarizes treatment guidelines and possible therapeutic schemes with antiresorptives for women on AI. Guidance from expert groups for premenopausal women with therapy-induced early menopause recommends the use of antiresorptives if the BMD Z-score is <2.0 [41]. In postmenopausal women, the consensus from expert panels recommends treatment with antiresorptives in patients receiving AI therapy with a T-score $<2.0$ or with two or more clinical risk factors for fracture [38].

Data from randomized clinical trials (RCTs) in $>5000$ patients show that bisphosphonates and denosumab administered at doses and schedules that are most often similar to those used for postmenopausal osteoporosis can prevent bone loss in women with breast cancer and even lead to an increase in BMD [38, 39]. The ABCSG-18 trial, which randomized postmenopausal women on AIs to denosumab $60 \mathrm{mg} \mathrm{q} 6 \mathrm{~m}$ or placebo, found that active treatment reduced the risk of first clinical fracture (the primary endpoint) relative to placebo by $50 \%$. Five years following randomization, $15 \%$ of placebo patients but little over $5 \%$ of denosumab-treated patients had experienced a fracture. A significant protective effect was seen both in women with a baseline T-score $<-1$ and in those with a T-score $\geq-1$ [40]. These new findings will have to be considered when updating guidelines for the prevention of AI-induced bone loss, especially given that denosumab was not associated with additional toxicity. In particular, there was no concern over osteonecrosis of the jaw or atypical femoral fractures [40]. Important additional evidence for the use of antiresorptives in the adjuvant setting is provided by the recent Early Breast Cancer Trialists' Collaborative Group (EBCTCG) meta-analysis of data from postmenopausal breast cancer patients showing that adjuvant zoledronic acid and clodronate could reduce recurrence rate and prolong survival. Compelling evidence from this meta-analysis of trial data of $>18,000$ patients supports clinically significant benefits of bisphosphonates on the development of bone metastases and breast cancer mortality in postmenopausal women or those receiving ovarian suppression therapy [47]. An international panel of experts has recently recommended that bisphosphonates, either iv zoledronic acid or oral clodronate, are considered as part of the adjuvant breast cancer treatment in this population. Data from the adjuvant use of denosumab in this setting are eagerly awaited [44, 48].

\section{Prostate Cancer}

Androgen deprivation therapy (ADT) is the cornerstone of treatment in prostate cancer but has several adverse effects, especially on bone health. ADT can be achieved by castration, luteinizing hormone-releasing hormone (LHRH) agonists or antagonists. Men undergoing ADT should have their bone health monitored for fracture risk [49]. As for breast cancer, FRAX underestimates the effects of hormone therapy on fracture risk. ADT leads to accelerated bone loss and an increase in fracture rate, as evidenced by 


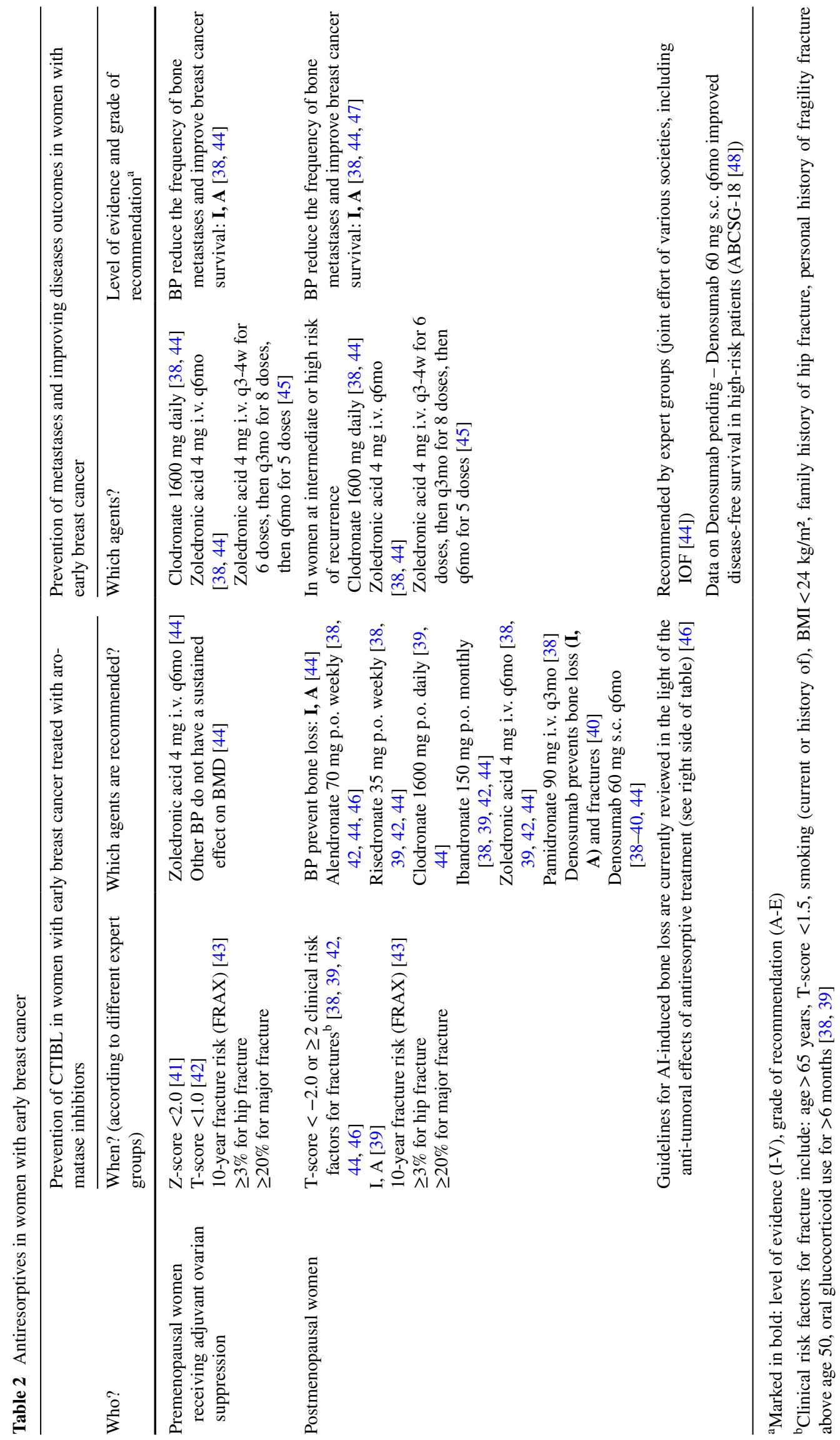


large retrospective epidemiological studies [50, 51]. Men treated with LHRH agonists lose 1-5\% of BMD within the first year and fracture risk increases with treatment duration [50]. A matched-cohort study of almost 20,000 men found that the risk of fragility fracture (all sites) was 17.2\% for those on ADT (mean duration 6.5 years) compared with $12.7 \%$ among men not on ADT (HR 1.65; 95\% CI 1.39-1.54) [51]. Increasing age is an independent risk factor for fractures, and fracture in prostate cancer more than doubles mortality. The recent introduction of the androgen synthesis inhibitor abiraterone for castration-resistant prostate cancer (CRPC) could aggravate the problem because of its impact on endogenous cortisone production. Abiraterone must indeed be combined with $10 \mathrm{mg}$ prednisone and ADT has to be continued anyway. Abiraterone and other new agents significantly extend overall survival in CRPC, so that prolonged exposure to steroids and ADT may be expected, potentially increasing the risk of osteoporotic fracture. Because of its favorable toxicity profile, abiraterone is especially suited to elderly who are not good candidates for chemotherapy [52].

Table 3 summarizes possible therapeutic schemes with antiresorptives for men on ADT. Alendronate, risedronate, zoledronic acid, and pamidronate have all been shown to prevent BMD loss in patients with locally advanced prostate cancer under ADT [38]. 6-12 monthly zoledronic acid and 6-monthly denosumab are most often used. Prostate cancer is essentially a disease of elderly men who are more likely than younger men to require dose adjustment for renal impairment, which makes denosumab more attractive than bisphosphonates. Moreover, only denosumab has a specific license for ADT-induced bone loss. In a placebocontrolled trial of denosumab in 1468 men receiving ADT for non-metastatic prostate cancer, 3 years of denosumab treatment at doses used for the treatment of osteoporosis led to a $62 \%$ relative reduction in new vertebral fractures [53]. Although antiresorptive therapies are especially important for elderly patients with cancer, they are typically underutilized in this population and guidelines for this indication have received less attention. They should probably be broadly similar to those in breast cancer and recent guidelines advocate that all men aged over 75 years under ADT should receive antiresorptive agents at doses used to prevent osteoporosis [46]. Underuse of antiresorptive therapies may be more detrimental in elderly compared with younger patients because of multiple fracture risk factors, including physiological decreases in BMD and increases in fracture rate with advancing age.

\section{Hematopoietic Stem Cell Transplantation}

Hematopoietic stem cell transplantation (HSCT) is the treatment of choice for many patients with malignant and

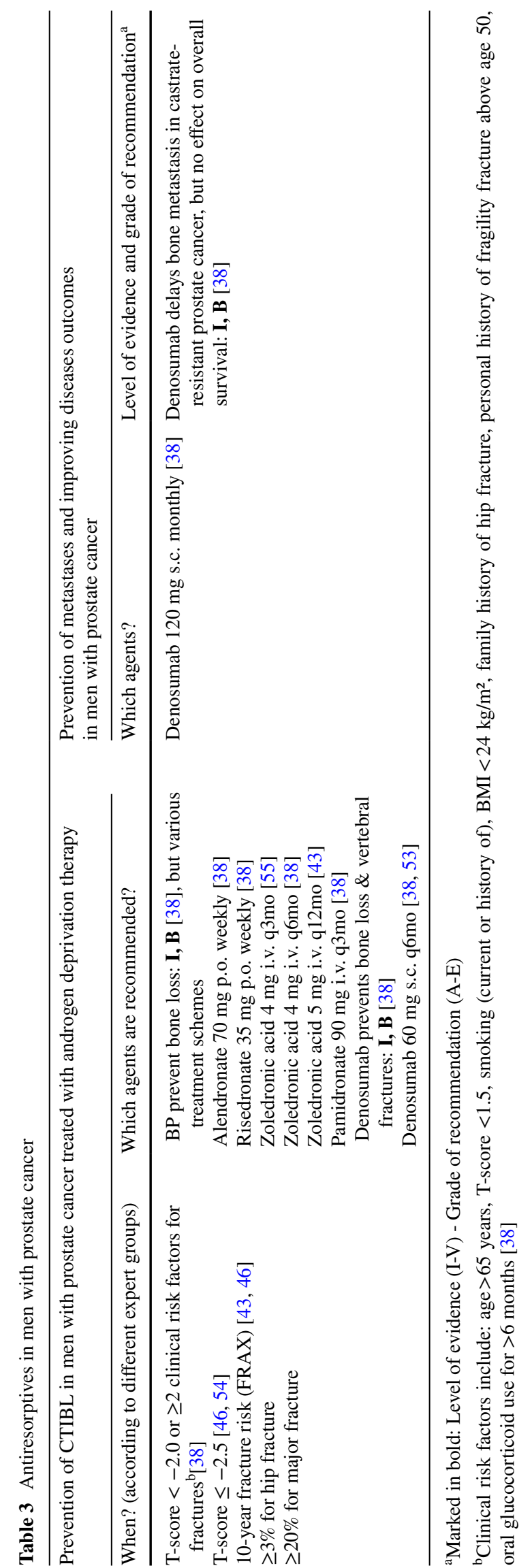


non-malignant hematological diseases. Osteoporotic fractures constitute one of the main long-term complications. The etiology of bone loss after HSCT is multifactorial, including the use of corticosteroids and other immunosuppressive drugs, release of inflammatory cytokines, and treatment-induced hypogonadism. Even if patients undergoing HSCT are most often less than 50 years, the incidence of osteopenia and osteoporosis in adults after HSCT approaches 50\% after 5 years and $20 \%$ after 2 years, respectively. The degree of bone loss is most often severe, especially after allo-HSCT, and cortical bone appears to be affected more than trabecular bone [56]. The relative risk of fractures is increased seven- to ninefold compared with 45- to 64-year-old adults in population-based cohort studies [57].

All HSCT patients should receive dietary and lifestyle advice, including calcium and vitamin D supplementation. Menopause hormone therapy (MHT) should be considered in menopausal women, and testosterone potentially in hypogonadal men. Antiresorptives used in this population are mostly bisphosphonates but there are few randomized trials [58]. The pamidronate trials included the largest number of patients and appear to be more representative of the real effects of bisphosphonates in this population. A randomized study including 99 patients under HSCT with or without five $60-\mathrm{mg}$ pamidronate infusions over 1 year showed that in the pamidronate group, BMD remained stable at lumbar spine but still decreased at the femoral neck and total hip [59]. In a smaller study, using higher doses of pamidronate, comparable to the doses used for the treatment of bone metastases, similar findings were reported [60]. There is no reported experience with denosumab in patients after HSCT.

\section{Conclusion}

To conclude, AIs, ADT, and HSCT are associated with bone loss and fracture risk. Therefore, individuals on these therapies should have their bone health monitored for fracture risk. The FRAX algorithm, however, does not consider anticancer treatment as a specific risk factor and thus underestimates the effect of these therapies. Cancer patients treated with AIs, ADT, and HSCT should receive dietary and lifestyle advice, including adequate calcium and vitamin D intake. Furthermore, in patients on AIs and ADT, bisphosphonates and denosumab administered at doses similar to the treatment of postmenopausal osteoporosis can prevent bone loss. Denosumab has also been shown to reduce fracture risk in both conditions. Moreover, antiresorptives in the adjuvant setting reduce recurrence rate in postmenopausal women with breast cancer. The few RCTs with bisphosphonates in adults with HSCT showed reduced bone loss, while MHT may be considered in menopausal women and testosterone in hypogonadal men.

\section{Osteoporosis in Sarcopenic Patients}

Sarcopenia corresponds to a progressive and generalized loss of muscle mass combined with either loss of muscle strength or physical performance [61]. Consequences of sarcopenia include physical disability, nursing home admissions, depression, hospitalizations, and mortality, thus an increased morbidity and mortality essentially similar to the consequences of osteoporosis.

During the last decade, bone and muscle were increasingly recognized as interacting tissues, not only because of their adjacent surfaces or as a result of the mechanical effects of muscle loading on bone [62]. The "bone-muscleunit" is now widely considered as the site of privileged exchanges in which the two tissues communicate via paracrine and endocrine signals to coordinate their development and adapt their response to loading and injury from embryologic stages to involution [63, 64]. During growth, muscle area seems closely correlated with bone parameters such as bone mineral content and femoral circumference. Growing evidence suggest that sarcopenia and osteoporosis share many common pathways including the sensitivity to reduced anabolic hormone secretion, increased inflammatory cytokine activity, anabolic or catabolic molecules released by the skeletal muscle or bone cells (i.e., myokines and osteokines), and eventually reduced physical activity $[64,65]$.

The concept bone-muscle-unit is evidenced phenotypically by the observation of a linear relationship between BMD and lean body mass at various ages [66]. The muscle-bone cross-talk is also supported by preclinical data, showing its presence even before birth in mammals [63]. The muscle secretome consists of several hundred secreted peptides, providing a whole new paradigm for understanding how muscles communicate with other organs, including bones [63]. Several molecules released by muscle affect bone, including IGF-1 (insulin-like growth factor-1), fibroblast-growth factor-2, interleukin (IL)-6, IL-15, myostatin, osteoglycin, FAM5C (family with sequence similarity 5, member C), Tmem119 (transmembrane protein 119), irisin, and osteoactivin [63]. However, much less studies were dedicated to studying the reverse channel (i.e., from bone to muscle). Both osteoblasts and osteocytes were shown to secrete cytokines. The effects on muscle of prostaglandin E2 and Wnt3A (wingless-type MMTV integration site family, member 3A) which are secreted by osteocytes, osteocalcin, and IGF-1, produced by osteoblasts, and sclerostin secreted by both cell types, are however well documented [63]. 
With adipose tissue also involved in the complex bone-muscle interaction came the suggestion that obesity, sarcopenia, and osteoporosis could be concomitantly found in a subset of the population, presenting with an entity called osteosarcopenic obesity [67]. The mechanism underlying this condition is an increase in total and/or abdominal adipose tissue that causes an increase in pro-inflammatory cytokines as well as some hormonal disturbances leading to losses of both muscle and bone. The decrease in muscle and bone is associated with a decrease in physical activity leading to a vicious cycle of progressive loss of muscle and bone and a gain in fat [67]. It is likely that these individuals will present with poorer clinical outcomes caused by the cascade of metabolic abnormalities associated with the changes in their body composition. This view was supported by the observation that obese subjects with low muscle mass (sarcopenia) or strength (dynapenia) have an increased risk of osteoporosis and non-vertebral fracture relative to obese alone counterparts. These findings imply that sarcopenic and dynapenic obese individuals require close monitoring of bone health during ageing.

\section{Bone-muscle Interaction in Clinical Trials}

Several studies support the in vivo association of low BMD and sarcopenia. In 679 men aged 40-79 years from the European Male Ageing Study, sarcopenia was associated with low BMD and osteoporosis [68]. Similarly, in 17,891 subjects from various ethnicities, each standard deviation increase in relative appendicular skeletal muscle mass resulted in a 37\% reduction in the risk of osteopenia/osteoporosis and subjects with sarcopenia were 2 times more likely to have osteopenia/osteoporosis [69].

In a study in 591 inpatients, sarcopenia was present in $64 \%$ of women and $95 \%$ of men who recently experienced a hip fracture [70]. Moreover, sarcopenia was associated with lower ability to perform activities of daily living compared to presarcopenia. This may reflect an increased risk of posthip fracture complications, additional health resources utilization, and higher incidence of contralateral hip fracture. In a population of young patients (20-69 years) with a femoral neck fracture, those with low-energy trauma have significantly lower femoral neck BMD and fat-free mass than those with other trauma mechanisms [71]. These results re-emphasize the association between low bone and muscle mass in patients with hip fractures, and the need for a comprehensive management of these patients.

Furthermore, in Chinese community-dwelling elderly aged 65 and older, sarcopenia was a predictor of fracture risk independent of BMD and other clinical risk factors, and the diagnosis of sarcopenia added incremental value to the FRAX algorithm in predicting incident fracture risk [72].
Finally, in a cross-sectional study in 680 men and women with a mean age of 79 years, sarco-osteoporotic individuals were more likely to have a lower MNA (mininutritional assessment) and BMI compared to normal elderly [73]. In Italian hip fracture patients, a low intake of calories, protein, and leucine was associated with reduced muscle mass [74]. This illustrates the importance of detecting nutritional deficits and optimizing nutritional status in patients with osteoporosis and sarcopenia in order to prevent poor clinical outcomes such as falls and fractures.

\section{Interventions Targeting both Muscle and Bone}

At this stage, no RCTs assessing the concomitant effects of a new chemical entity (NCE) on bone and muscle have been published. This may be, in part, related to the absence of guidelines supporting regulatory studies for NCE to manage sarcopenia [75]. However, a better understanding of the interconnection of bone and muscle may shift our treatment paradigm to "kill two birds with one stone," i.e., to treat sarcopenic patients and prevent fractures, as suggested by Gingis et al. [64].

A potential strategy is to target pathways that centrally regulate both bone and muscle (e.g., growth hormone (GH) and GH secretagogues, androgens, selective androgen receptor modulators, and vitamin D) or to investigate newly emerging pathways that might facilitate the communication between the two tissues (e.g., activin signaling inhibitors, including myostatin-neutralizing antibodies/propeptides, recombinant follistatin, follistatin derivatives, and soluble activin receptors or myokines) [63, 64]. An overview of the results of human clinical studies with these agents has recently been published [64].

All authors acknowledge the critical importance of regular exercise and adequate nutrition to optimize peak bone mass and maintain bone and muscle health throughout live $[63,67]$. In this perspective, two intervention trials are worth a comment. Bauer et al. reported, in a well-designed 13-week RCT, the beneficial effects of a vitamin D- and leucine-enriched whey protein oral supplement on muscle mass and lower-extremity function among sarcopenic elderly [76]. Knowing the importance of vitamin D and proteins for bone health, this nutritional supplement could also take place in the armamentarium against osteoporosis $[77,78]$. Chahal et al. investigated the impact of various intensities and frequencies of loading doses of physical activity on knee extension torque and broadband ultrasound attenuation at the heel in middle-aged women. They concluded that physical activity, especially at high intensity level and high frequency range, may have beneficial effects on muscle strength and bone density in this population [79]. 


\section{Conclusion}

Osteoporosis and sarcopenia are two disorders predominantly affecting elderly patients and responsible for a major clinical and financial burden. Increase in life expectancy in most countries and in both sexes makes their diagnosis, prevention, and treatment a major social and ethical, yet unmet, medical need. Genetic, developmental, paracrine, endocrine, and lifestyle factors have dual effects on bone mass and muscle mass and function.

The evidence of biochemical and molecular interactions between the two tissues needs to be further explored for the development of NCE against these twin conditions of aging. Targeting pathways that centrally regulate bone and muscle or newly pathways that facilitate communication between the two tissues are the directions for the identification of NCE, which could simultaneously prevent, reduce, or restore bone and muscle wasting. It seems wise for companies developing such agents to include, within the secondary endpoints of their trials, outcomes parameters (e.g., DXA, biochemical markers, imaging, quality of life) reflecting the effect of these drugs on bone and muscle. However, the importance of physical exercise and the need for a balanced diet providing sufficient amounts of proteins, calcium, vitamin $\mathrm{D}$, and various micronutrients should not be underestimated.

\section{Osteoporosis in the Oldest Old}

\section{Osteoporosis and Osteoporotic Fractures in Old Age: A Challenge}

The incidence of osteoporotic fractures increases with age. Today, the cumulative incidence of hip fractures in women at the age of 80 is close to $30 \%$ [80]. Vertebral fractures are even more common, with a prevalence of more than $40 \%$ in women older than 80 [81]. Moreover, the burden of osteoporosis will only increase in the future because of the aging of the population. In Belgium, it is expected that the number of osteoporotic fractures will increase with $25 \%$ in the next 10 years. Osteoporosis in old age is a challenge because of its significant burden in terms of morbidity, mortality, and economic cost.

\section{Elderly Persons with Osteoporosis are Frail Elderly}

According to the World Report on Ageing and Health of the World Health Organization (WHO) [82], healthy aging is the process of developing and maintaining the functional ability that enables well-being in older age. Functional ability is made up of the intrinsic capacity of the individual (the composite of all the physical and mental capacities of the individual), relevant environmental characteristics, and the interactions between the individual and the environment. An individual may have reserves of functional ability that he or she is not drawing on. These reserves contribute to the resilience of the individual. Resilience is the ability to maintain or improve a level of functional ability in the face of adverse events. Frailty can be considered as the progressive age-related decline in physiological systems that results in decreased reserves of intrinsic capacity, which leads to extreme vulnerability to stressors and increases the risk of adverse health outcomes [83].

Elderly patients with osteoporotic fractures are not "average" elderly, but should be considered as frail persons, with a high prevalence of underlying comorbidities and at risk of functional deficits [84]. Indeed, in old age, osteoporosis and osteoporotic fractures tend to occur in a particularly frail subset of the population [85]. This frailty will be reflected in poor post-fracture outcomes, such as functional decline, loss of quality of life, and an increased mortality which continues to be observed more than 10 years after the fracture [86].

\section{Under-diagnosis and Under-Treatment of Osteoporosis in Old Age}

Despite the increasing evidence for the frequency and severity of osteoporosis in the elderly, osteoporosis continues to be under-diagnosed and under-treated, particularly in individuals over the age of 80 . This may, at least partly, be explained by the fact that evidence of the anti-fracture efficacy of osteoporosis treatment comes mainly from RCTs in women with a mean age of 70 to 75 years. Thus, there is an urgent need for treatment options with documented efficacy in older individuals, not only against vertebral fractures but even more so against non-vertebral fractures, as these account for most of the morbidity and mortality associated with osteoporosis. Treatment options should also be proven to be safe in elderly who are frail, with comorbidities and at increased risk of adverse events.

\section{Treatment of Osteoporosis in the Oldest Old}

In this chapter, the evidence about the efficacy and safety of the available osteoporosis therapies in the elderly, and especially the oldest old ( $\geq 80$ year), is discussed. Nonpharmacological interventions such as fall prevention strategies play an essential role in the treatment of osteoporosis, also in elderly, but will not be discussed.

\section{Calcium and Vitamin D Supplementation in old Age}

One of the main determinants of bone loss in old age is calcium and vitamin D deficiency and that is why combined 
calcium and vitamin D supplementation has become one of the main components to reduce bone loss and fracture risk in old age. Low levels of 25-hydroxyvitamin D (25OHD) occur in all age groups; $2-30 \%$ of adults in European countries have a serum $25 \mathrm{OHD}$ level below $10 \mathrm{ng} / \mathrm{ml}$, but this may rise to more than $80 \%$ in institutionalized elderly [87]. In fact, a gradual decline of $25 \mathrm{OHD}$ is observed from healthy adults over independent elderly to institutionalized persons and hip fracture patients [87]. Despite the observation that the absorption of vitamin $\mathrm{D}_{3}$ and its metabolism into 25OHD and 1,25-dihydroxyvitamin $\mathrm{D}\left(1,25(\mathrm{OH})_{2} \mathrm{D}\right)$ is well preserved in elderly without liver or kidney disease, elderly are at risk of hypovitaminosis D because of low vitamin D intake and decreased capacity of the skin to produce vitamin $\mathrm{D}_{3}$ together with less sun exposure [87]. Therefore, elderly and especially those in institutions have lower levels of 25OHD compared to young individuals. Hypovitaminosis D lowers the intestinal calcium absorption and induces a negative calcium balance, which may be enhanced by insufficient calcium intake. This stimulates the secretion of PTH, which enhances bone turnover, induces osteoporosis and increases fracture risk. Low vitamin D may also increase fracture risk by increasing the risk of falling apparently through an effect on balance and muscle strength [78].

Adequate vitamin D status is therefore essential in the prevention of bone loss and osteoporotic fractures. A daily intake of $800 \mathrm{IU}$ of vitamin D is recommended for individuals aged $\geq 71$ years in order to achieve a serum 25OHD level of at least $20 \mathrm{ng} / \mathrm{ml}$ as this meets the requirements of at least $97.5 \%$ of the population [88]. One of the reasons why individual RCTs and meta-analyses failed to show a reduction in fracture risk with calcium and vitamin $\mathrm{D}$ may be the lack of targeting of supplementation to persons at risk of a negative calcium balance and/or vitamin D deficiency, such as individuals aged $\geq 75$ years and institutionalized elderly. This is illustrated by a recent meta-analysis that found that vitamin $\mathrm{D}$ with calcium reduced the risk of hip fractures in institutionalized but not in communitydwelling elderly as the latter group is less likely to have calcium and/or vitamin D deficiency [89].

Thus, combined supplementation with calcium and vita$\min \mathrm{D}$ is an essential component to reduce bone loss and fracture risk in the elderly. However, osteoporosis treatment, on top of calcium and vitamin D, should be considered in older individuals with osteoporosis and osteoporotic fractures.

\section{Pharmacological Osteoporosis Treatment in Old Age}

Table 4 gives an overview of the anti-fracture evidence of currently approved pharmacological osteoporosis medication in old age.
Alendronate The efficacy of alendronate as an antiresorptive agent was established by the Fracture Intervention Trial (FIT) in postmenopausal women with a prevalent vertebral fracture as well as in postmenopausal women with a T-score $\leq-1.6$ at the femoral neck (mean age 70.8 and 67.7 years, respectively) [101, 102].

A post hoc analysis of the FIT-trial has evaluated the anti-fracture efficacy of alendronate in postmenopausal women with the highest fracture risk. This analysis included a subgroup with patients aged $\geq 75$ years (range 75-82 years) [90]. After 3 years, alendronate significantly reduced the risk of vertebral fracture by $38 \%$ (RR $0.62 ; 95 \% \mathrm{CI}$ $0.41-0.94$ ) in women aged $\geq 75$ years compared to $51 \%$ in the younger age group (RR $0.49 ; 95 \%$ CI $0.35-0.68$ ). This study was followed by another analysis based on pooled data from both FIT arms [91]. Focus of this analysis was to calculate age-specific fracture rates ( 55 to $<65$ years, 65 to $<70$ years, 70 to $<75$ years, and $75-85$ years). Relative risk reductions for hip (RR 0.47; 95\% CI 0.27-0.81) and vertebral (RR 0.55 ; 95\% CI 0.37-0.83) fractures were constant among age groups, with an even greater absolute risk reduction as age increases. This greater absolute risk reduction was explained by the age-related increase in fracture risk in the placebo group. Finally, also a very recent study showed that alendronate in patients older than 80 years who had a prior fracture was associated with a reduced hip fracture risk (HR 0.72; 95\% CI 0.61-0.85) [92]. The reduction in hip fracture risk was maintained across all age quartiles and the absolute risk reduction at 5 years increased substantially by quartile of age. Moreover, adverse events were not more common in the higher age quartiles.

Risedronate In 1999 and 2000, the VERT-trials demonstrated the efficacy of risedronate to prevent vertebral and non-vertebral fractures in postmenopausal women (mean age approximately 70 years) $[103,104]$. In 2001, the effect on hip fracture risk was examined in the HIP-trial, of which one arm included postmenopausal women with a mean age of 74 years [93].

The other arm of the HIP-trial included 3886 women aged $\geq 80$ years with a low femoral neck BMD or at least one non-skeletal risk factor for hip fracture (e.g., poor gait or a propensity to fall) [93]. After 3 years, no reduction in hip fracture risk was observed. Of note, the majority of the participants was selected based on non-skeletal risk factors [93]. A second analysis was a pooled analysis of the VERTand HIP-trials in 1392 women with osteoporosis aged $\geq 80$ years [94]. After 3 years, the risk of vertebral fractures was reduced by $44 \%$ (HR 0.56 ; 95\% CI $0.39-0.81$ ). The incidence of non-vertebral fractures was not significantly different.

The difference in benefit for vertebral versus non-vertebral fractures in the elderly might be explained by the fact 
Table 4 Relative risk (95\% CI) of new vertebral, hip and non-vertebral fractures compared with placebo in very elderly women receiving currently available osteoporosis treatments

\begin{tabular}{|c|c|c|c|c|c|c|c|}
\hline & $\mathrm{RCT}$ & $\begin{array}{l}\text { Included } \\
\text { participants }\end{array}$ & $\mathrm{N}$ & $\begin{array}{l}\text { Mean age } \\
\text { (years) }\end{array}$ & Vertebral fractures & Hip fractures & $\begin{array}{l}\text { Non-vertebral } \\
\text { fractures }\end{array}$ \\
\hline \multirow[t]{3}{*}{ Alendronate } & $\begin{array}{l}\text { Post hoc } \\
\text { analysis FIT } \\
\text { Vertebral } \\
\text { Fracture } \\
\text { Arm (3 } \\
\text { years) [90] }\end{array}$ & $\begin{array}{l}\text { Women aged } \\
75-82 \text { years }\end{array}$ & 539 & $\begin{array}{l}\text { Not speci- } \\
\text { fied }\end{array}$ & $\begin{array}{l}\text { RR 0.62 } \\
\text { 95\% CI 0.41-0.94 } \\
\boldsymbol{p}<0.05 \\
p_{\text {interact }}<75 \& \geq 75 \text { years } \\
\quad \text { NS }\end{array}$ & - & - \\
\hline & 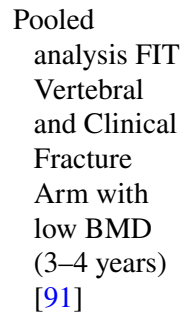 & $\begin{array}{l}\text { Women aged } \\
55-80 \text { years } \\
55-<65 \\
\text { years } \\
65-<70 \\
\text { years } \\
70-<75 \\
\text { years } \\
75-85 \text { years }\end{array}$ & 3658 & & $\begin{array}{l}\text { RR } 0.55 \\
\text { 95\% CI 0.37-0.83 } \\
\text { (constant RR) }\end{array}$ & $\begin{array}{l}\text { RR 0.47 } \\
\text { 95\% CI 0.27-0.81 } \\
\text { (constant RR) }\end{array}$ & - \\
\hline & $\begin{array}{l}\text { Axelsson } \\
\text { et al. [92] } \\
\text { (5 years) }\end{array}$ & $\begin{array}{l}\text { Women aged } \\
71.1-92.3 \\
\text { years with } \\
\text { a prior } \\
\text { fracture }\end{array}$ & 110,190 & 82.4 Years & - & $\begin{array}{l}\text { HR 0.72 } \\
95 \% \text { CI 0.61-0.85 } \\
p<0.001\end{array}$ & - \\
\hline \multirow[t]{2}{*}{ Risedronate } & $\begin{array}{l}\text { HIP - arm } 2 \\
\text { (3 years) } \\
\text { [93] }\end{array}$ & $\begin{array}{l}\text { Women } \\
\text { aged } \geq 80 \\
\text { years } \\
\text { with at least } \\
\text { one non- } \\
\text { skeletal risk } \\
\text { factor for } \\
\text { hip fracture } \\
\text { or T-score at } \\
\text { FN } \leq 4 \text { or } \\
\leq 3+\text { hip } \\
\text { axis } \\
\text { length of } \\
\geq 11.1 \mathrm{~cm}\end{array}$ & 3886 & 83 Years & - & $\begin{array}{l}\mathrm{RR}=0.8 \\
95 \% \text { CI } 0.6-1.2 \\
p=0.35\end{array}$ & $\begin{array}{c}10.8 \% \text { (Risedronate) } \\
\text { versus } 11.9 \% \text { (pla- } \\
\text { cebo); } p=0.43\end{array}$ \\
\hline & $\begin{array}{l}\text { Post hoc } \\
\text { pooled } \\
\text { analysis } \\
\text { VERT-NA, } \\
\text { VERT-MN } \\
\text { and HIP (3 } \\
\text { years) [94] }\end{array}$ & $\begin{array}{l}\text { Women } \\
\text { aged } \geq 80 \text { y } \\
\text { with T-score } \\
\leq 2.5 \text { at } \\
\text { FN or at } \\
\text { least one } \\
\text { prevalent } \\
\text { vertebral } \\
\text { fracture }\end{array}$ & 1392 & 83 years & $\begin{array}{l}\text { HR 0.56 } \\
95 \% \text { CI } 0.39-0.81 \\
\boldsymbol{p}=\mathbf{0 . 0 0 3} \\
\mathrm{p}_{\text {interact }<80 \& \geq 85 \text { years }} \\
\quad \mathrm{NS}\end{array}$ & - & $\begin{array}{l}14.0 \% \text { (Risedronate) } \\
\text { versus } 16.2 \% \\
\quad \text { (placebo) } \\
p=0.66\end{array}$ \\
\hline $\begin{array}{l}\text { Zoledronic } \\
\text { acid }\end{array}$ & $\begin{array}{l}\text { Post hoc } \\
\text { analysis } \\
\text { HORIZON- } \\
\text { PFT and } \\
\text { RFT (3 } \\
\text { years) [95] }\end{array}$ & $\begin{array}{l}\text { Women } \\
\text { aged } \geq 75 \\
\text { years with } \\
\text { T-score } \leq \\
-2.5 \text { at FN } \\
\text { or } \geq 1 \text { ver- } \\
\text { tebral or hip } \\
\text { fracture }\end{array}$ & 3888 & 79.4 years & $\begin{array}{l}\text { HR } 0.34 \\
\text { 95\% CI 0.21-0.55 } \\
\boldsymbol{p}<\mathbf{0 . 0 0 1} \\
p_{\text {interact }}<75 \& \geq 75 \text { years } \\
\quad \text { NS }\end{array}$ & 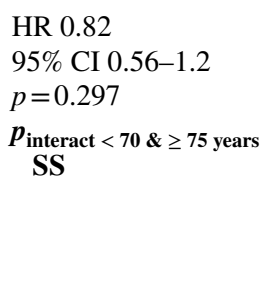 & $\begin{array}{l}\text { HR 0.73 } \\
\text { 95\% CI 0.60-0.90 } \\
\boldsymbol{p}=\mathbf{0 . 0 0 2} \\
p_{\text {interact }<70 \& \geq 75 \text { years }} \\
\quad \text { NS }\end{array}$ \\
\hline
\end{tabular}


Table 4 (continued)

\begin{tabular}{|c|c|c|c|c|c|c|c|}
\hline & RCT & $\begin{array}{l}\text { Included } \\
\text { participants }\end{array}$ & $\mathrm{N}$ & $\begin{array}{l}\text { Mean age } \\
\text { (years) }\end{array}$ & Vertebral fractures & Hip fractures & $\begin{array}{l}\text { Non-vertebral } \\
\text { fractures }\end{array}$ \\
\hline \multirow[t]{2}{*}{ Denosumab } & $\begin{array}{l}\text { Post hoc } \\
\text { analysis } \\
\text { FREEDOM } \\
\text { (3 years) } \\
{[96]}\end{array}$ & $\begin{array}{l}\text { Women } \\
\text { aged } \geq 75 \\
\text { years }\end{array}$ & 2471 & 78.2 years & - & $\begin{array}{l}\mathbf{0 . 9} \%(\text { denosumab) } \\
\text { versus } 2.3 \%(\text { pla- } \\
\text { cebo) } \\
\text { p }<0.01 ; \text { ARR } 1.4 \% \\
p_{\text {interact }}<75 \& \geq 75 \text { years } \\
\quad \text { NS }\end{array}$ & - \\
\hline & $\begin{array}{l}\text { Preplanned } \\
\text { analysis } \\
\text { FREEDOM } \\
\text { (3 years) } \\
{[97]}\end{array}$ & $\begin{array}{l}\text { Women } \\
\text { aged } \geq 75 \\
\text { years }\end{array}$ & 2471 & 78.2 & $\begin{array}{l}\text { RR } 0.36 \\
\mathbf{9 5 \%} \text { CI } 0.25-\mathbf{0 . 5 3} \\
p_{\text {interact }}<75 \& \geq 75 \text { years } \\
\quad \text { NS }\end{array}$ & - & $\begin{array}{l}\text { RR } 0.84 \\
95 \% \text { CI } 0.63-1.12 \\
p_{\text {interact }}<75 \& \geq 75 \text { years } \\
\quad \text { NS }\end{array}$ \\
\hline \multirow[t]{2}{*}{$\begin{array}{l}\text { Strontium } \\
\text { ranelate }\end{array}$} & $\begin{array}{l}\text { Preplanned } \\
\text { pooled } \\
\text { analysis } \\
\text { SOTI and } \\
\text { TROPOS (3 } \\
\text { years) [98] }\end{array}$ & $\begin{array}{l}\text { Women aged } \\
80-100 \\
\text { years }\end{array}$ & 1488 & 83.5 years & $\begin{array}{l}\text { RR 0.68 } \\
95 \% \text { CI } 0.50-0.92 \\
p=0.013\end{array}$ & $\begin{array}{l}\text { RR } 0.68 \\
95 \% \text { CI } 0.42-1.10 \\
p=0.112 \\
\text { (not powered) }\end{array}$ & $\begin{array}{l}\text { RR 0.69 } \\
95 \% \text { CI 0.52-0.92 } \\
p=0.011\end{array}$ \\
\hline & $\begin{array}{l}\text { Preplanned } \\
\text { pooled } \\
\text { analysis } \\
\text { SOTI and } \\
\text { TROPOS (5 } \\
\text { years) [99] }\end{array}$ & $\begin{array}{l}\text { Women aged } \\
80-100 \\
\text { years }\end{array}$ & 1489 & 83.5 years & $\begin{array}{l}\text { RR 0.69 } \\
\text { 95\% CI 0.52-0.92 }\end{array}$ & $\begin{array}{l}\text { RR } 0.76 \\
95 \% \text { CI } 0.50-1.15 \\
\text { (not powered) }\end{array}$ & $\begin{array}{l}\text { RR } 0.73 \\
95 \% \text { CI } 0.57-0.95\end{array}$ \\
\hline Teriparatide & $\begin{array}{l}\text { Prespecified } \\
\text { subgroup } \\
\text { analysis } \\
\text { FPT (19 } \\
\text { months) } \\
\text { [100] }\end{array}$ & $\begin{array}{l}\text { Women } \\
\text { aged } \geq 75 \\
\text { years }\end{array}$ & 244 & 78.3 years & $\begin{array}{l}\text { RR } \mathbf{0 . 3 5} \\
\boldsymbol{p}<\mathbf{0 . 0 5} \\
\mathrm{p}_{\text {interact }<75 \& \geq 75 \text { years }} \\
\quad \mathrm{NS}\end{array}$ & - & $\begin{array}{l}\text { RR } 0.75 ; p=0.661 \\
\text { (not powered) } \\
p_{\text {interact }<75 \& \geq 75 \text { years }} \\
\quad \mathrm{NS}\end{array}$ \\
\hline
\end{tabular}

Results in bold indicate significant results

$F N$ femoral neck, $L S$ lumbar spine, $y$ years, ITT intention to treat, $N S$ not significant

that bisphosphonates impact on BMD, illustrated by the significant reduction of vertebral fractures. Bisphosphonates, however, do not impact on non-skeletal risk factors of fractures such as gait disturbances, impaired balance, and fall risk. These non-skeletal factors are of particular importance in the occurrence of non-vertebral fractures in the elderly, as they are more prone to falling. In contrast, vertebral fractures are often atraumatic, thus less influenced by non-skeletal risk factors. An additional explanation for this discrepancy between the older and younger population in preventing non-vertebral fractures, might be insufficient statistical power in the older age group.

Ibandronate No data are available on the anti-fracture efficacy of ibandronate in the very elderly.

Zoledronic Acid The HORIZON Pivotal Fracture Trial (HORIZON-PFT) showed that zoledronic acid is an effective therapy in postmenopausal women (mean age 73 years), with a reduction in the risk of vertebral, hip, and non-vertebral fractures [105]. In the HORIZON-Recurrent Fracture
Trial (HORIZON-RFT), zoledronic acid reduced the risk of new vertebral and non-vertebral fractures in patients with a hip fracture (mean age 74.4 years) [106].

In 2010, a post hoc pooled analysis of both HORIZON trials that focused on women aged $\geq 75$ years with osteoporosis was published (mean age 79.4 years) [95]. After 3 years, the incidence of vertebral and non-vertebral fracture was significantly lower in the treated group compared to the placebo group (HR $0.34 ; 95 \%$ CI $0.21-0.55$ and HR 0.73 ; 95\% CI 0.6-0.9, respectively). The benefit was comparable with the risk reduction in subjects $<75$ years in HORIZON-PFT and HORIZON-RFT. However, contrary to younger persons, the reduction in hip fracture risk did not meet statistical significance in patients $\geq 75$ years. As mentioned above, possibly the sample size was not powered to detect hip fracture risk reduction in the older age group. Another explanation is the greater influence of nonskeletal risk factors for hip fractures with increasing age.

Denosumab In women with a mean age of 72.3 years, denosumab has been established as a safe and effective therapy 
by the FREEDOM trial, with a significant risk reduction of vertebral, hip and non-vertebral fractures [107].

A post hoc analysis of FREEDOM was carried out in 2011 to evaluate the effect of denosumab in persons aged $\geq 75$ years [96]. In this group (mean age 78.2 years), denosumab significantly reduced the risk of hip fractures by $62 \%$, comparable with the risk reduction in the overall FREEDOM study population. Moreover, no significant difference in adverse events was observed in the older subgroup [96]. In 2012, another analysis of FREEDOM confirmed that denosumab reduces the risk of vertebral and non-vertebral fractures in subjects older than 75 years (RR 0.36 ; 95\% CI $0.25-0.53$ and RR 0.84 ; 95\% CI $0.63-1.12$, respectively) to the same extent as in younger subjects (RR 0.30 ; $95 \%$ CI $0.22-0.41$ and RR 0.78 ; $95 \%$ CI $0.63-0.96$ ) [97]. Moreover, treatment safety and efficacy of denosumab are not affected by renal function, so elderly with renal impairment will experience the same anti-fracture efficacy as patients with normal renal function [108]. However, since the use of denosumab is associated with a high rate of severe hypocalcemia in patients with advanced CKD, close monitoring and replacement of calcium and vitamin $\mathrm{D}$ is required to avoid the development of hypocalcemia in these patients.

Thus, denosumab is an effective therapy to prevent vertebral, non-vertebral, and hip fractures in the elderly, in contrast to bisphosphonates with no significant reduction in hip fracture risk by risedronate and zoledronic acid. As mentioned, this might be explained by lack of statistical power. However, it is tempting to speculate that this observation is due to the mechanism of denosumab, different from that of bisphosphonates, with distinct effects on cortical bone. Cortical porosity is indeed one of the main determinants of non-vertebral fracture risk, including hip fracture risk.

Strontium Ranelate The anti-fracture efficacy of strontium ranelate was established by two trials, SOTI and TROPOS, in women with a mean age of 69.3 and 76.7 years, respectively $[109,110]$.

A preplanned pooled analysis of both trials was undertaken to confirm these results in patients older than 80 years [99]. After 5 years, the risk of vertebral and nonvertebral fractures was reduced by $31 \%$ (RR $0.69 ; 95 \% \mathrm{CI}$ $0.52-0.92$ ) and $27 \%$ (RR 0.73 ; 95\%CI 0.57-0.95), respectively [99]. The numbers needed to treat were lower in women aged $\geq 80$ years than in younger women. This is because a similar relative risk reduction in both age groups will avert more fractures in the older age group which has a higher baseline fracture risk [98]. Statistical significance for hip fracture risk reduction was not reached, but the analyses were not designed to quantify the reduction in hip fracture risk.
Thus, these analyses showed a significant reduction in the risk of vertebral and non-vertebral fractures in persons aged $\geq 80$ years treated with strontium ranelate. However, the finding of an increased risk of cardiac events, including myocardial infarction, in addition to the already recognized risk of venous thromboembolism, has limited its use in clinical practice, although it remains a useful alternative in elderly with severe osteoporosis, unable to take other treatment and without cardiovascular contraindications [111].

Anabolic Therapy Daily injections of teriparatide reduce the risk of vertebral and non-vertebral fractures, as shown in the Fracture Prevention Trial (FPT) in women (mean age 69.5 years) with a prior vertebral fracture [112].

A prespecified subgroup analysis of the FPT-study was undertaken in 2006 to investigate the effect of teriparatide in persons aged 75 years and older (mean age 78.3 years) [100]. In this subgroup, $5.2 \%$ in the teriparatide group and $15.1 \%$ in the placebo group had a new vertebral fracture after 19 months. Treatment-by-age interaction was not significant, indicating that the effect of teriparatide was not statistically different in younger and older patients. Also for non-vertebral fractures, the treatment-by-age interaction was not significant. There was no significant difference in the safety profile between younger and older participants. So, age does not affect the safety and efficacy of teriparatide in preventing fractures. The major disadvantage, however, is the daily subcutaneous administration which may be a burden for elderly.

Also for abaloparatide, a novel 34-amino acid PTHrelated peptide $(\mathrm{PTHrP})$ which significantly reduced the risk of new vertebral and non-vertebral fractures in the Abaloparatide Comparator Trial in Vertebral Endpoints (ACTIVE), there was a consistent fracture risk reduction across different age groups ( $<65$ vs. 65 to $<75$ vs. $\geq 75$ years) [113].

\section{Conclusion}

In old age, osteoporosis and osteoporotic fractures tend to occur in a particularly frail subset of the population. Treatment of osteoporosis is of particular concern in the elderly because of the substantial burden of osteoporotic fractures in terms of morbidity, mortality, and economic cost. Calcium and vitamin $\mathrm{D}$ is an essential component in the management of osteoporosis in old age. Adding osteoporosis treatment reduces the risk of fractures even more, at least in older individuals with documented osteoporosis and at least for vertebral fractures and maybe also for hip fractures. In frail elderly with documented osteoporosis, treatment may even be more effective than in younger patients. 


\section{General Conclusions}

In this consensus paper, we reviewed the evidence about the evaluation and management of osteoporosis in frail persons. This is of particular concern because of the major burden of osteoporotic fractures in terms of morbidity and mortality in frail individuals such as patients with AN, dialysis and cancer patients, persons with sarcopenia, and the oldest old.

AIs, ADT, and HSCT in cancer patients are associated with increased bone loss and fracture risk, as are dialysis status, old age, and AN. Sarcopenia is also associated with low BMD. Low muscle and bone mass results in a decrease in physical activity, ultimately leading to osteosarcopenic obesity.

Therefore, individuals treated with AIs, ADT, and HSCT, as well as elderly and/or sarcopenic individuals and patients with AN should have their bone health monitored for fracture risk with DXA. Until recently, DXA was not recommended in dialysis patients, but this may change in future as recent data suggest that DXA may also predict fractures and maybe even mortality in dialysis patients. In the FRAX algorithm, age and BMI, but not anticancer treatments, dialysis status, and sarcopenia are considered as specific risk factors. Therefore, the effect of these later conditions on fracture risk may be underestimated by this algorithm.

In all these frail individuals, a healthy lifestyle should be recommended, consisting of physical exercise (except in $\mathrm{AN}$ ), adequate calcium and vitamin $\mathrm{D}$ intake, and certainly in persons with AN and osteosarcopenic obesity, recovering a normal BMI. Furthermore, in patients on $\mathrm{AI}$ and ADT, bisphosphonates and denosumab administered at doses similar to the treatment of postmenopausal osteoporosis are recommended to prevent bone loss and reduce fracture risk. After HSCT, also testosterone may be considered in hypogonadal men and MHT in menopausal women. AN adolescents may also be treated with MHT, while antiresorptives and/or anabolics are only indicated in adults, not adolescents, with AN. Similarly, in elderly, antiresorptive and/or anabolic treatment is indicated to prevent osteoporotic fractures. As compared to younger individuals, elderly have a higher absolute risk reduction because of their higher baseline fracture risk. In dialysis patients, there are few studies, although some data suggest a positive effect of bisphosphonates, in lower dosages than used in the general population, and of denosumab which is, however, associated with a higher risk of severe hypocalcemia. Antiresorptives should be avoided in dialysis patients with low bone turnover, in whom teriparatide may be of theoretical interest. Finally, more research is needed to develop pharmacological therapies that have a concomitant effect on muscle and bone.
To conclude, frail individuals are at risk of bone loss and fractures. Therefore, in these patients, it is advised to regularly monitor bone health by DXA or, if available, other techniques such as QCT. FRAX may not always adequately predict fracture risk. Strategies to prevent bone loss and fractures include advising a healthy lifestyle as well as initiating specific osteoporosis therapy. Further research is needed to determine the role of new osteoporosis medication in frail individuals as well to develop medication that target not only bone, but also concomitant affected systems such as muscles and the cardiovascular system.

\section{Compliance with Ethical Standards}

Conflict of interest E. Gielen, P. Bergmann, O. Bruyère, E. Cavalier, P. Delanaye, S. Goemaere, J.-M. Kaufman, M. Locquet, J.-Y. Reginster, S. Rozenberg, A.-M. Vandenbroucke, and J.-J. Body declare that they have no conflict of interest related to this manuscript.

Human and Animal Rights and Informed Consent This article does not contain any studies with human participants or animals performed by any of the authors.

Open Access This article is distributed under the terms of the Creative Commons Attribution 4.0 International License (http:// creativecommons.org/licenses/by/4.0/), which permits unrestricted use, distribution, and reproduction in any medium, provided you give appropriate credit to the original author(s) and the source, provide a link to the Creative Commons license, and indicate if changes were made.

\section{References}

1. Forman S (2016) Eating disorders: Overview of epidemiology, clinical features, and diagnosis Uptodate

2. Grinspoon S, Thomas E, Pitts S, Gross E, Mickley D, Miller K, Herzog D, Klibanski A (2000) Prevalence and predictive factors for regional osteopenia in women with anorexia nervosa. Ann Intern Med 133(10):790-794

3. Misra M, Klibanski A (2006) Anorexia nervosa and osteoporosis. Rev Endocr Metab Disord 7(1-2):91-99

4. Veronese N, Solmi M, Rizza W, Manzato E, Sergi G, Santonastaso P, Caregaro L, Favaro A, Correll CU (2015) Vitamin $\mathrm{D}$ status in anorexia nervosa: a meta-analysis. Int J Eat Disord 48(7):803-813

5. Misra M, Klibanski A (2014) Anorexia nervosa and bone. J Endocrinol 221(3):R163-R176

6. Theintz G, Buchs B, Rizzoli R, Slosman D, Clavien H, Sizonenko PC, Bonjour JP (1992) Longitudinal monitoring of bone mass accumulation in healthy adolescents: evidence for a marked reduction after 16 years of age at the levels of lumbar spine and femoral neck in female subjects. J Clin Endocrinol Metab 75(4):1060-1065

7. Rigotti NA, Neer RM, Skates SJ, Herzog DB, Nussbaum SR (1991) The clinical course of osteoporosis in anorexia nervosa. A longitudinal study of cortical bone mass. JAMA 265(9):1133-1138

8. Vestergaard P, Emborg C, Stoving RK, Hagen C, Mosekilde L, Brixen K (2002) Fractures in patients with anorexia 
nervosa, bulimia nervosa, and other eating disorders-a nationwide register study. Int J Eat Disord 32(3):301-308

9. Lewiecki EM, Gordon CM, Baim S, Binkley N, Bilezikian JP, Kendler DL, Hans DB, Silverman S, Bishop NJ, Leonard MB, Bianchi ML, Kalkwarf HJ, Langman CB, Plotkin H, Rauch F, Zemel BS (2008) Special report on the 2007 adult and pediatric Position Development Conferences of the International Society for Clinical Densitometry. Osteoporos Int 19(10):1369-1378

10. Misra M, Katzman D, Miller KK, Mendes N, Snelgrove D, Russell M, Goldstein MA, Ebrahimi S, Clauss L, Weigel T, Mickley D, Schoenfeld DA, Herzog DB, Klibanski A (2011) Physiologic estrogen replacement increases bone density in adolescent girls with anorexia nervosa. J Bone Miner Res 26(10):2430-2438

11. Strokosch GR, Friedman AJ, Wu SC, Kamin M (2006) Effects of an oral contraceptive (norgestimate/ethinyl estradiol) on bone mineral density in adolescent females with anorexia nervosa: a double-blind, placebo-controlled study. J Adolesc Health 39(6):819-827

12. Lawson S, Miller K (2016) Anorexia nervosa: endocrine complications and their management. Uptodate

13. Miller KK, Meenaghan E, Lawson EA, Misra M, Gleysteen S, Schoenfeld D, Herzog D, Klibanski A (2011) Effects of risedronate and low-dose transdermal testosterone on bone mineral density in women with anorexia nervosa: a randomized, placebo-controlled study. J Clin Endocrinol Metab 96(7):2081-2088

14. Golden NH, Iglesias EA, Jacobson MS, Carey D, Meyer W, Schebendach J, Hertz S, Shenker IR (2005) Alendronate for the treatment of osteopenia in anorexia nervosa: a randomized, double-blind, placebo-controlled trial. J Clin Endocrinol Metab 90(6):3179-3185

15. Losada I, Sartori L, Di Gianantonio E, Zen M, Clementi M, Doria A (2010) Bisphosphonates in patients with autoimmune rheumatic diseases: Can they be used in women of childbearing age? Autoimmun Rev 9(8):547-552

16. Jadoul M, Albert JM, Akiba T, Akizawa T, Arab L, BraggGresham JL, Mason N, Prutz KG, Young EW, Pisoni RL (2006) Incidence and risk factors for hip or other bone fractures among hemodialysis patients in the Dialysis Outcomes and Practice Patterns Study. Kidney Int 70(7):1358-1366

17. Alem AM, Sherrard DJ, Gillen DL, Weiss NS, Beresford SA, Heckbert SR, Wong C, Stehman-Breen C (2000) Increased risk of hip fracture among patients with end-stage renal disease. Kidney Int 58(1):396-399

18. Coco M, Rush H (2000) Increased incidence of hip fractures in dialysis patients with low serum parathyroid hormone. Am J Kidney Dis 36(6):1115-1121

19. Cunningham J, Sprague SM, Cannata-Andia J, Coco M, CohenSolal M, Fitzpatrick L, Goltzmann D, Lafage-Proust MH, Leonard M, Ott S, Rodriguez M, Stehman-Breen C, Stern P, Weisinger J, Osteoporosis Work G (2004) Osteoporosis in chronic kidney disease. Am J Kidney Dis 43(3):566-571

20. Miller PD (2014) Bone disease in CKD: a focus on osteoporosis diagnosis and management. Am J Kidney Dis 64(2):290-304

21. Salam SN, Eastell R, Khwaja A (2014) Fragility fractures and osteoporosis in CKD: pathophysiology and diagnostic methods. Am J Kidney Dis 63(6):1049-1059

22. Moorthi RN, Moe SM (2013) Recent advances in the noninvasive diagnosis of renal osteodystrophy. Kidney Int 84(5):886-894

23. Kidney Disease: Improving Global Outcomes CKDMBDWG (2009) KDIGO clinical practice guideline for the diagnosis, evaluation, prevention, and treatment of Chronic Kidney Disease-Mineral and Bone Disorder (CKD-MBD). Kidney Int Suppl 76(113):S1-130
24. Delanaye P, Souberbielle JC, Lafage-Proust MH, Jean G, Cavalier E (2014) Can we use circulating biomarkers to monitor bone turnover in CKD haemodialysis patients? Hypotheses and facts. Nephrol Dial Transplant 29(5):997-1004

25. Iimori S, Mori Y, Akita W, Kuyama T, Takada S, Asai T, Kuwahara M, Sasaki S, Tsukamoto Y (2012) Diagnostic usefulness of bone mineral density and biochemical markers of bone turnover in predicting fracture in CKD stage 5D patients-a single-center cohort study. Nephrol Dial Transplant 27(1):345-351

26. Jamal SA, Hayden JA, Beyene J (2007) Low bone mineral density and fractures in long-term hemodialysis patients: a metaanalysis. Am J Kidney Dis 49(5):674-681

27. Taal MW, Roe S, Masud T, Green D, Porter C, Cassidy MJ (2003) Total hip bone mass predicts survival in chronic hemodialysis patients. Kidney Int 63(3):1116-1120

28. Vasikaran S, Eastell R, Bruyere O, Foldes AJ, Garnero P, Griesmacher A, McClung M, Morris HA, Silverman S, Trenti T, Wahl DA, Cooper C, Kanis JA, Group I-IBMSW (2011) Markers of bone turnover for the prediction of fracture risk and monitoring of osteoporosis treatment: a need for international reference standards. Osteoporos Int 22(2):391-420

29. Malluche HH, Davenport DL, Cantor T, Monier-Faugere MC (2014) Bone mineral density and serum biochemical predictors of bone loss in patients with CKD on dialysis. Clin J Am Soc Nephrol 9(7):1254-1262

30. Moe SM, Abdalla S, Chertow GM, Parfrey PS, Block GA, Correa-Rotter R, Floege J, Herzog CA, London GM, Mahaffey KW, Wheeler DC, Dehmel B, Goodman WG, Drueke TB, Evaluation of Cinacalcet HTtLCETI (2015) Effects of cinacalcet on fracture events in patients receiving hemodialysis: the EVOLVE trial. J Am Soc Nephrol 26(6):1466-1475

31. Investigators ET, Chertow GM, Block GA, Correa-Rotter R, Drueke TB, Floege J, Goodman WG, Herzog CA, Kubo Y, London GM, Mahaffey KW, Mix TC, Moe SM, Trotman ML, Wheeler DC, Parfrey PS (2012) Effect of cinacalcet on cardiovascular disease in patients undergoing dialysis. N Engl J Med 367(26):2482-2494

32. Bergner R (2013) Bisphosphonate therapy in renal osteodystrophy - a review. J Nephrol 26(3):450-455

33. Hernandez E, Valera R, Alonzo E, Bajares-Lilue M, Carlini R, Capriles F, Martinis R, Bellorin-Font E, Weisinger JR (2003) Effects of raloxifene on bone metabolism and serum lipids in postmenopausal women on chronic hemodialysis. Kidney Int 63(6):2269-2274

34. D'Haese PC, Schrooten I, Goodman WG, Cabrera WE, Lamberts LV, Elseviers MM, Couttenye MM, De Broe ME (2000) Increased bone strontium levels in hemodialysis patients with osteomalacia. Kidney Int 57(3):1107-1114

35. Hiramatsu R, Ubara Y, Sawa N, Hoshino J, Hasegawa E, Kawada M, Imafuku A, Sumida K, Mise K, Hayami N, Suwabe T, Takaichi K (2015) Denosumab for low bone mass in hemodialysis patients: a noncontrolled trial. Am J Kidney Dis 66(1):175-177

36. Giamalis P, Economidou D, Dimitriadis C, Memmos D, Papagianni A, Efstratiadis G (2015) Treatment of adynamic bone disease in a haemodialysis patient with teriparatide. Clin Kidney J 8(2): 188-190

37. Moe SM, Chen NX, Newman CL, Organ JM, Kneissel M, Kramer I, Gattone VH 2nd, Allen MR (2015) Anti-sclerostin antibody treatment in a rat model of progressive renal osteodystrophy. J Bone Miner Res 30(3):499-509

38. Coleman R, Body JJ, Aapro M, Hadji P, Herrstedt J, Group EGW (2014) Bone health in cancer patients: ESMO Clinical Practice Guidelines. Ann Oncol 25(Suppl 3):iii124-i137

39. Hadji P, Aapro MS, Body JJ, Bundred NJ, Brufsky A, Coleman RE, Gnant M, Guise T, Lipton A (2011) Management of 
aromatase inhibitor-associated bone loss in postmenopausal women with breast cancer: practical guidance for prevention and treatment. Ann Oncol 22(12):2546-2555

40. Gnant M, Pfeiler G, Dubsky PC, Hubalek M, Greil R, Jakesz R, Wette V, Balic M, Haslbauer F, Melbinger E, Bjelic-Radisic V, Artner-Matuschek S, Fitzal F, Marth C, Sevelda P, Mlineritsch B, Steger GG, Manfreda D, Exner R, Egle D, Bergh J, Kainberger F, Talbot S, Warner D, Fesl C, Singer CF, Austrian B, Colorectal Cancer Study G (2015) Adjuvant denosumab in breast cancer (ABCSG-18): a multicentre, randomised, doubleblind, placebo-controlled trial. Lancet 386 (9992):433-443

41. Hadji P, Gnant M, Body JJ, Bundred NJ, Brufsky A, Coleman RE, Guise TA, Lipton A, Aapro MS (2012) Cancer treatmentinduced bone loss in premenopausal women: a need for therapeutic intervention? Cancer Treat Rev 38(6):798-806

42. Reid DM, Doughty J, Eastell R, Heys SD, Howell A, McCloskey EV, Powles T, Selby P, Coleman RE (2008) Guidance for the management of breast cancer treatment-induced bone loss: a consensus position statement from a UK Expert Group. Cancer Treat Rev 34(Suppl 1):S3-S18

43. Gralow JR, Biermann JS, Farooki A, Fornier MN, Gagel RF, Kumar R, Litsas G, McKay R, Podoloff DA, Srinivas S, Van Poznak CH (2013) NCCN task force report: bone health in cancer care. J Natl Compr Canc Netw 11 Suppl 3:S1-50; quiz S51

44. Hadji P, Coleman RE, Wilson C, Powles TJ, Clezardin P, Aapro M, Costa L, Body JJ, Markopoulos C, Santini D, Diel I, Di Leo A, Cameron D, Dodwell D, Smith I, Gnant M, Gray R, Harbeck $\mathrm{N}$, Thurlimann B, Untch M, Cortes J, Martin M, Albert US, Conte PF, Ejlertsen B, Bergh J, Kaufmann M, Holen I (2016) Adjuvant bisphosphonates in early breast cancer: consensus guidance for clinical practice from a European Panel. Ann Oncol 27(3):379-390

45. Coleman R, Cameron D, Dodwell D, Bell R, Wilson C, Rathbone E, Keane M, Gil M, Burkinshaw R, Grieve R, Barrett-Lee P, Ritchie D, Liversedge V, Hinsley S, Marshall H, investigators A (2014) Adjuvant zoledronic acid in patients with early breast cancer: final efficacy analysis of the AZURE (BIG 01/04) randomised open-label phase 3 trial. Lancet Oncol 15(9):997-1006

46. Body JJ, Terpos E, Tombal B, Hadji P, Arif A, Young A, Aapro M, Coleman R (2016) Bone health in the elderly cancer patient: A SIOG position paper. Cancer Treat Rev 51:46-53

47. Early Breast Cancer Trialists' Collaborative G, Coleman R, Powles T, Paterson A, Gnant M, Anderson S, Diel I, Gralow J, von Minckwitz G, Moebus V, Bergh J, Pritchard KI, Bliss J, Cameron D, Evans V, Pan H, Peto R, Bradley R, Gray R (2015) Adjuvant bisphosphonate treatment in early breast cancer: meta-analyses of individual patient data from randomised trials. The Lancet 386(10001):1353-1361

48. Gnant M, Pfeiler G, Hubalek M, Greil R, Wette V, Balic M The Impact of Adjuvant Denosumab on Disease-free Survival in Postmenopausal Patients With Hormone Receptor Positive Breast Cancer: L: Results from 3425 postmenopausal patients of the ABCSG-18 trial. In: San Antonio Breast Cancer Symposium, 2015.

49. Lee CE, Leslie WD, Czaykowski P, Gingerich J, Geirnaert M, Lau YK (2011) A comprehensive bone-health management approach for men with prostate cancer receiving androgen deprivation therapy. Curr Oncol 18(4):e163-e172

50. Shahinian VB, Kuo YF, Freeman JL, Goodwin JS (2005) Risk of fracture after androgen deprivation for prostate cancer. $\mathrm{N}$ Engl J Med 352(2):154-164

51. Alibhai SM, Duong-Hua M, Cheung AM, Sutradhar R, Warde P, Fleshner NE, Paszat L (2010) Fracture types and risk factors in men with prostate cancer on androgen deprivation therapy: a matched cohort study of 19,079 men. J Urol 184(3):918-923
52. Body JJ, Casimiro S, Costa L (2015) Targeting bone metastases in prostate cancer: improving clinical outcome. Nat Rev Urol 12(6):340-356

53. Smith MR, Egerdie B, Hernandez Toriz N, Feldman R, Tammela TL, Saad F, Heracek J, Szwedowski M, Ke C, Kupic A, Leder BZ, Goessl C, Denosumab HPCSG (2009) Denosumab in men receiving androgen-deprivation therapy for prostate cancer. N Engl J Med 361(8):745-755

54. Cornford P, Bellmunt J, Bolla M, Briers E, De Santis M, Gross T, Henry AM, Joniau S, Lam TB, Mason MD, van der Poel HG, van der Kwast TH, Rouviere O, Wiegel T, Mottet N (2016) EAU-ESTRO-SIOG guidelines on prostate cancer. Part II: treatment of relapsing, metastatic, and castration-resistant prostate cancer. Eur Urol

55. Smith MR, Eastham J, Gleason DM, Shasha D, Tchekmedyian S, Zinner N (2003) Randomized controlled trial of zoledronic acid to prevent bone loss in men receiving androgen deprivation therapy for nonmetastatic prostate cancer. J Urol 169(6):2008-2012

56. Bhatia S (2011) Long-term health impacts of hematopoietic stem cell transplantation inform recommendations for followup. Expert Rev Hematol 4(4):437-452 (quiz 453-434)

57. Pundole XN, Barbo AG, Lin H, Champlin RE, Lu H (2015) Increased incidence of fractures in recipients of hematopoietic stem-cell transplantation. J Clin Oncol 33(12):1364-1370

58. Majhail NS, Rizzo JD, Lee SJ, Aljurf M, Atsuta Y, Bonfim C, Burns LJ, Chaudhri N, Davies S, Okamoto S, Seber A, Socie G, Szer J, Van Lint MT, Wingard JR, Tichelli A, Center for International B, Marrow Transplant R, American Society for B, Marrow T, European Group for B, Marrow T, Asia-Pacific B, Marrow Transplantation G, Bone Marrow Transplant Society of A, New Z, East Mediterranean B, Marrow Transplantation G, Sociedade Brasileira de Transplante de Medula O (2012) Recommended screening and preventive practices for long-term survivors after hematopoietic cell transplantation. Biol Blood Marrow Transplant 18 (3):348-371

59. Kananen K, Volin L, Laitinen K, Alfthan H, Ruutu T, Valimaki MJ (2005) Prevention of bone loss after allogeneic stem cell transplantation by calcium, vitamin D, and sex hormone replacement with or without pamidronate. J Clin Endocrinol Metab 90(7):3877-3885

60. Grigg AP, Shuttleworth P, Reynolds J, Schwarer AP, Szer J, Bradstock K, Hui C, Herrmann R, Ebeling PR (2006) Pamidronate reduces bone loss after allogeneic stem cell transplantation. J Clin Endocrinol Metab 91(10):3835-3843

61. Cruz-Jentoft AJ, Baeyens JP, Bauer JM, Boirie Y, Cederholm T, Landi F, Martin FC, Michel JP, Rolland Y, Schneider SM, Topinkova E, Vandewoude M, Zamboni M, European Working Group on Sarcopenia in Older P (2010) Sarcopenia: European consensus on definition and diagnosis: Report of the European Working Group on Sarcopenia in Older People. Age Ageing 39(4):412-423

62. Reginster JY, Beaudart C, Buckinx F, Bruyere O (2016) Osteoporosis and sarcopenia: two diseases or one? Curr Opin Clin Nutr Metab Care 19(1):31-36

63. Tagliaferri C, Wittrant Y, Davicco MJ, Walrand S, Coxam V (2015) Muscle and bone, two interconnected tissues. Ageing Res Rev 21:55-70

64. Girgis CM, Mokbel N, Digirolamo DJ (2014) Therapies for musculoskeletal disease: can we treat two birds with one stone? Curr Osteoporos Rep 12(2):142-153

65. Laurent MR, Dubois V, Claessens F, Verschueren SM, Vanderschueren D, Gielen E, Jardi F (2015) Muscle-bone interactions: From experimental models to the clinic? A critical update. Mol Cell Endocrinol 432:14-36 
66. Ferretti JL, Capozza RF, Cointry GR, Garcia SL, Plotkin H, Alvarez Filgueira ML, Zanchetta JR (1998) Gender-related differences in the relationship between densitometric values of whole-body bone mineral content and lean body mass in humans between 2 and 87 years of age. Bone 22(6):683-690

67. Ormsbee MJ, Prado CM, Ilich JZ, Purcell S, Siervo M, Folsom A, Panton L (2014) Osteosarcopenic obesity: the role of bone, muscle, and fat on health. J Cachexia Sarcopenia Muscle 5(3):183-192

68. Verschueren S, Gielen E, O'Neill TW, Pye SR, Adams JE, Ward KA, Wu FC, Szulc P, Laurent M, Claessens F, Vanderschueren D, Boonen S (2013) Sarcopenia and its relationship with bone mineral density in middle-aged and elderly European men. Osteoporos Int 24(1):87-98

69. He H, Liu Y, Tian Q, Papasian CJ, Hu T, Deng HW (2016) Relationship of sarcopenia and body composition with osteoporosis. Osteoporos Int 27(2):473-482

70. Di Monaco M, Castiglioni C, Vallero F, Di Monaco R, Tappero $R$ (2012) Sarcopenia is more prevalent in men than in women after hip fracture: a cross-sectional study of 591 inpatients. Arch Gerontol Geriatr 55(2):e48-e52

71. Al-Ani AN, Cederholm T, Saaf M, Neander G, Blomfeldt R, Ekstrom W, Hedstrom M (2015) Low bone mineral density and fat-free mass in younger patients with a femoral neck fracture. Eur J Clin Invest 45(8):800-806

72. Yu R, Leung J, Woo J (2014) Incremental predictive value of sarcopenia for incident fracture in an elderly Chinese cohort: results from the Osteoporotic Fractures in Men (MrOs) Study. J Am Med Dir Assoc 15(8):551-558

73. Huo YR, Suriyaarachchi P, Gomez F, Curcio CL, Boersma D, Gunawardene P, Demontiero O, Duque G (2015) Comprehensive nutritional status in sarco-osteoporotic older fallers. J Nutr Health Aging 19(4):474-480

74. Calvani R, Martone AM, Marzetti E, Onder G, Savera G, Lorenzi M, Serafini E, Bernabei R, Landi F (2014) Pre-hospital dietary intake correlates with muscle mass at the time of fracture in older hip-fractured patients. Front Aging Neurosci 6:269

75. Reginster JY, Cooper C, Rizzoli R, Kanis JA, Appelboom G, Bautmans I, Bischoff-Ferrari HA, Boers M, Brandi ML, Bruyere O, Cherubini A, Flamion B, Fielding RA, Gasparik AI, Van Loon L, McCloskey E, Mitlak BH, Pilotto A, ReiterNiesert S, Rolland Y, Tsouderos Y, Visser M, Cruz-Jentoft AJ (2016) Recommendations for the conduct of clinical trials for drugs to treat or prevent sarcopenia. Aging Clin Exp Res 28(1):47-58

76. Bauer JM, Verlaan S, Bautmans I, Brandt K, Donini LM, Maggio M, McMurdo ME, Mets T, Seal C, Wijers SL, Ceda GP, De Vito G, Donders G, Drey M, Greig C, Holmback U, Narici M, McPhee J, Poggiogalle E, Power D, Scafoglieri A, Schultz R, Sieber CC, Cederholm T (2015) Effects of a vitamin D and leucine-enriched whey protein nutritional supplement on measures of sarcopenia in older adults, the PROVIDE study: a randomized, double-blind, placebo-controlled trial. J Am Med Dir Assoc 16(9):740-747

77. Rizzoli R, Stevenson JC, Bauer JM, van Loon LJ, Walrand S, Kanis JA, Cooper C, Brandi ML, Diez-Perez A, Reginster JY, Force ET (2014) The role of dietary protein and vitamin D in maintaining musculoskeletal health in postmenopausal women: a consensus statement from the European Society for Clinical and Economic Aspects of Osteoporosis and Osteoarthritis (ESCEO). Maturitas 79(1):122-132

78. Beaudart C, Buckinx F, Rabenda V, Gillain S, Cavalier E, Slomian J, Petermans J, Reginster JY, Bruyere O (2014) The effects of vitamin D on skeletal muscle strength, muscle mass, and muscle power: a systematic review and meta-analysis of randomized controlled trials. J Clin Endocrinol Metab 99(11):4336-4345

79. Chahal J, Lee R, Luo J (2014) Loading dose of physical activity is related to muscle strength and bone density in middle-aged women. Bone 67:41-45

80. Cooper C, Campion G, Melton LJ 3rd (1992) Hip fractures in the elderly: a world-wide projection. Osteoporos Int 2(6):285-289

81. Grados F, Marcelli C, Dargent-Molina P, Roux C, Vergnol JF, Meunier PJ, Fardellone P (2004) Prevalence of vertebral fractures in French women older than 75 years from the EPIDOS study. Bone 34(2):362-367

82. World Health Organization (2015) World report on ageing and health

83. Cesari M, Prince M, Thiyagarajan JA, De Carvalho IA, Bernabei R, Chan P, Gutierrez-Robledo LM, Michel JP, Morley JE, Ong P, Rodriguez Manas L, Sinclair A, Won CW, Beard J, Vellas B (2016) Frailty: an emerging public health priority. J Am Med Dir Assoc 17(3):188-192

84. Gielen E, Verschueren S, O'Neill TW, Pye SR, O'Connell MD, Lee DM, Ravindrarajah R, Claessens F, Laurent M, Milisen K, Tournoy J, Dejaeger M, Wu FC, Vanderschueren D, Boonen S (2012) Musculoskeletal frailty: a geriatric syndrome at the core of fracture occurrence in older age. Calcif Tissue Int 91(3):161-177

85. Boonen S, Autier P, Barette M, Vanderschueren D, Lips P, Haentjens P (2004) Functional outcome and quality of life following hip fracture in elderly women: a prospective controlled study. Osteoporos Int 15(2):87-94

86. Haentjens P, Magaziner J, Colon-Emeric CS, Vanderschueren D, Milisen K, Velkeniers B, Boonen S (2010) Meta-analysis: excess mortality after hip fracture among older women and men. Ann Intern Med 152(6):380-390

87. Lips P (2001) Vitamin D deficiency and secondary hyperparathyroidism in the elderly: consequences for bone loss and fractures and therapeutic implications. Endocr Rev 22(4):477-501

88. Institute of Medicine (ed) (2011) Dietary reference intakes for calcium and vitamin D. The National Academies Press, Washington, DC

89. Bolland MJ, Grey A, Gamble GD, Reid IR (2014) The effect of vitamin D supplementation on skeletal, vascular, or cancer outcomes: a trial sequential meta-analysis. Lancet Diabetes Endocrinol 2(4):307-320

90. Ensrud KE, Black DM, Palermo L, Bauer DC, Barrett-Connor E, Quandt SA, Thompson DE, Karpf DB (1997) Treatment with alendronate prevents fractures in women at highest risk: results from the Fracture Intervention Trial. Arch Intern Med 157(22):2617-2624

91. Hochberg MC, Thompson DE, Black DM, Quandt SA, Cauley J, Geusens P, Ross PD, Baran D, Group FITR (2005) Effect of alendronate on the age-specific incidence of symptomatic osteoporotic fractures. J Bone Miner Res 20(6):971-976

92. Axelsson K, Lundh D, Lorentzon M (2016) Alendronate treatment is associated with reduced fracture risk and maintained safety in the oldest old. Paper presented at the ASBMR Annual Meeting, Atlanta

93. McClung MR, Geusens P, Miller PD, Zippel H, Bensen WG, Roux C, Adami S, Fogelman I, Diamond T, Eastell R, Meunier PJ, Reginster JY, Hip Intervention Program Study G (2001) Effect of risedronate on the risk of hip fracture in elderly women. Hip Intervention Program Study Group. N Engl J Med 344(5):333-340

94. Boonen S, McClung MR, Eastell R, El-Hajj Fuleihan G, Barton IP, Delmas P (2004) Safety and efficacy of risedronate in reducing fracture risk in osteoporotic women aged 80 and older: 
implications for the use of antiresorptive agents in the old and oldest old. J Am Geriatr Soc 52(11):1832-1839

95. Boonen S, Black DM, Colon-Emeric CS, Eastell R, Magaziner JS, Eriksen EF, Mesenbrink P, Haentjens P, Lyles KW (2010) Efficacy and safety of a once-yearly intravenous zoledronic acid $5 \mathrm{mg}$ for fracture prevention in elderly postmenopausal women with osteoporosis aged 75 and older. J Am Geriatr Soc 58(2):292-299

96. Boonen S, Adachi JD, Man Z, Cummings SR, Lippuner K, Torring O, Gallagher JC, Farrerons J, Wang A, Franchimont N, San Martin J, Grauer A, McClung M (2011) Treatment with denosumab reduces the incidence of new vertebral and hip fractures in postmenopausal women at high risk. J Clin Endocrinol Metab 96(6):1727-1736

97. McClung MR, Boonen S, Torring O, Roux C, Rizzoli R, Bone HG, Benhamou CL, Lems WF, Minisola S, Halse J, Hoeck HC, Eastell R, Wang A, Siddhanti S, Cummings SR (2012) Effect of denosumab treatment on the risk of fractures in subgroups of women with postmenopausal osteoporosis. J Bone Miner Res 27(1):211-218

98. Seeman E, Vellas B, Benhamou C, Aquino JP, Semler J, Kaufman JM, Hoszowski K, Varela AR, Fiore C, Brixen K, Reginster JY, Boonen S (2006) Strontium ranelate reduces the risk of vertebral and nonvertebral fractures in women eighty years of age and older. J Bone Miner Res 21(7):1113-1120

99. Seeman E, Boonen S, Borgstrom F, Vellas B, Aquino JP, Semler J, Benhamou CL, Kaufman JM, Reginster JY (2010) Five years treatment with strontium ranelate reduces vertebral and nonvertebral fractures and increases the number and quality of remaining life-years in women over 80 years of age. Bone 46(4):1038-1042

100. Boonen S, Marin F, Mellstrom D, Xie L, Desaiah D, Krege JH, Rosen CJ (2006) Safety and efficacy of teriparatide in elderly women with established osteoporosis: bone anabolic therapy from a geriatric perspective. J Am Geriatr Soc 54(5):782-789

101. Black DM, Cummings SR, Karpf DB, Cauley JA, Thompson DE, Nevitt MC, Bauer DC, Genant HK, Haskell WL, Marcus R, Ott SM, Torner JC, Quandt SA, Reiss TF, Ensrud KE (1996) Randomised trial of effect of alendronate on risk of fracture in women with existing vertebral fractures. Fracture Intervention Trial Research Group. The Lancet 348(9041):1535-1541

102. Cummings SR, Black DM, Thompson DE, Applegate WB, Barrett-Connor E, Musliner TA, Palermo L, Prineas R, Rubin SM, Scott JC, Vogt T, Wallace R, Yates AJ, LaCroix AZ (1998) Effect of alendronate on risk of fracture in women with low bone density but without vertebral fractures: results from the Fracture Intervention Trial. JAMA 280(24):2077-2082

103. Harris ST, Watts NB, Genant HK, McKeever CD, Hangartner T, Keller M, Chesnut CH 3rd, Brown J, Eriksen EF, Hoseyni MS, Axelrod DW, Miller PD (1999) Effects of risedronate treatment on vertebral and nonvertebral fractures in women with postmenopausal osteoporosis: a randomized controlled trial. Vertebral Efficacy With Risedronate Therapy (VERT) Study Group. JAMA 282(14):1344-1352
104. Reginster J, Minne HW, Sorensen OH, Hooper M, Roux C, Brandi ML, Lund B, Ethgen D, Pack S, Roumagnac I, Eastell R (2000) Randomized trial of the effects of risedronate on vertebral fractures in women with established postmenopausal osteoporosis. Vertebral Efficacy with Risedronate Therapy (VERT) Study Group. Osteoporos Int 11(1):83-91

105. Black DM, Delmas PD, Eastell R, Reid IR, Boonen S, Cauley JA, Cosman F, Lakatos P, Leung PC, Man Z, Mautalen C, Mesenbrink P, Hu H, Caminis J, Tong K, Rosario-Jansen T, Krasnow J, Hue TF, Sellmeyer D, Eriksen EF, Cummings SR, Trial HPF (2007) Once-yearly zoledronic acid for treatment of postmenopausal osteoporosis. N Engl J Med 356(18):1809-1822

106. Lyles KW, Colon-Emeric CS, Magaziner JS, Adachi JD, Pieper CF, Mautalen C, Hyldstrup L, Recknor C, Nordsletten L, Moore KA, Lavecchia C, Zhang J, Mesenbrink P, Hodgson PK, Abrams K, Orloff JJ, Horowitz Z, Eriksen EF, Boonen S, for the HRFT (2007) Zoledronic acid in reducing clinical fracture and mortality after hip fracture. N Engl J Med. doi:10.1056/ NEJMoa074941

107. Cummings SR, San Martin J, McClung MR, Siris ES, Eastell R, Reid IR, Delmas P, Zoog HB, Austin M, Wang A, Kutilek S, Adami S, Zanchetta J, Libanati C, Siddhanti S, Christiansen C, Trial F (2009) Denosumab for prevention of fractures in postmenopausal women with osteoporosis. N Engl J Med 361(8):756-765

108. Jamal SA, Ljunggren O, Stehman-Breen C, Cummings SR, McClung MR, Goemaere S, Ebeling PR, Franek E, Yang YC, Egbuna OI, Boonen S, Miller PD (2011) Effects of denosumab on fracture and bone mineral density by level of kidney function. J Bone Miner Res 26(8):1829-1835

109. Meunier PJ, Roux C, Seeman E, Ortolani S, Badurski JE, Spector TD, Cannata J, Balogh A, Lemmel EM, Pors-Nielsen S, Rizzoli R, Genant HK, Reginster JY (2004) The effects of strontium ranelate on the risk of vertebral fracture in women with postmenopausal osteoporosis. N Engl J Med 350(5):459-468

110. Reginster JY, Seeman E, De Vernejoul MC, Adami S, Compston J, Phenekos C, Devogelaer JP, Curiel MD, Sawicki A, Goemaere S, Sorensen OH, Felsenberg D, Meunier PJ (2005) Strontium ranelate reduces the risk of nonvertebral fractures in postmenopausal women with osteoporosis: treatment of peripheral osteoporosis (TROPOS) study. J Clin Endocrinol Metab 90(5):2816-2822

111. European Medicines Agency (2013) Protelos-H-C-560-PSU-31: EPAR-Assessment Report-Periodic safety update report.

112. Neer RM, Arnaud CD, Zanchetta JR, Prince R, Gaich GA, Reginster JY, Hodsman AB, Eriksen EF, Ish-Shalom S, Genant HK, Wang O, Mitlak BH (2001) Effect of parathyroid hormone (1-34) on fractures and bone mineral density in postmenopausal women with osteoporosis. N Engl J Med 344(19):1434-1441

113. Cosman F, Hattersley G, Hu MY, Williams GC, Fitzpatrick LA, Black DM (2016) Effects of abaloparatide-SC on fractures and bone mineral density in subgroups of postmenopausal women with osteoporosis and varying baseline risk factors. J Bone Miner Res. doi:10.1002/jbmr.2991 